NBER WORKING PAPER SERIES

\title{
AN ALTERNATIVE INTERPRETATION OF THE 'RESOURCE CURSE': THEORY AND POLICY IMPLICATIONS
}

\author{
Ricardo Hausmann \\ Roberto Rigobon \\ Working Paper 9424 \\ http://www.nber.org/papers/w9424 \\ NATIONAL BUREAU OF ECONOMIC RESEARCH \\ 1050 Massachusetts Avenue \\ Cambridge, MA 02138 \\ December 2002
}

Paper prepared for the Conference on Fiscal Policy Formulation and Implementation in Oil Producing Countries organized by the International Monetary Fund on June 5-6, 2002. We are indebted to Dani Rodrik and Andres Velasco for useful comments. The views expressed herein are those of the authors and not necessarily those of the National Bureau of Economic Research.

(C) 2002 by Ricardo Hausmann and Roberto Rigobon. All rights reserved. Short sections of text not to exceed two paragraphs, may be quoted without explicit permission provided that full credit including, (C) notice, is given to the source. 
An Alternative Interpretation of the 'Resource Curse': Theory and Policy Implications

Ricardo Hausmann and Robert Rigobon

NBER Working Paper No. 9424

December 2002

JEL No. F0

\section{ABSTRACT}

The existence of a natural resource curse has been a longstanding theme in the economic literature and in policy discussions. We propose an alternative mechanism and study its policy implications. The mechanism is based on the interaction between two building blocks: specialization in non-tradables and financial market imperfections. We show that if a country has a sufficiently large non-resource tradable sector, relative prices can be stable, even when the resource sector generates significant volatility in the demand for non-tradables. However, when the non-resource tradable sector disappears, the economy becomes much more volatile, because shocks to the demand for non-tradables - possibly associated with shocks to resource income - will not be accommodated by movements in the allocation of labor but instead by expenditure-switching. This requires much higher relative price movements. The presence of bankruptcy costs makes interest rates dependent on relative price volatility. These two effects interact causing the economy to specialize inefficiently away from non-resource tradables: the less it produces of them, the greater the volatility of relative prices, the higher the interest rate the sector faces, causing it to shrink even further until it disappears. At that point, the economy will face an even higher interest rate and a lower level of capital and output in the non-tradable sector. An increase in resource income that leads to specialization causes a large decline in welfare: thus the idea of the curse. Specialization is determined by the expected size and volatility in resource income. The paper justifies stabilization and savings policies as well as policies to make financial markets more efficient. However, we also find some support for more interventionist second-best trade and financial

Ricardo Hausmann

Kennedy School of Government

Harvard University

79 JFK Street

Cambridge, MA 02138
Roberto Rigobon

Sloan School of Management

MIT, E52-447

50 Memorial Drive

Cambridge, MA 02142

and NBER

rigobon@mit.edu 
It is often said that most people when reading about a theory wonder if it works in practice. Economists when they see things working in practice, wonder if they work in theory. The natural resource curse is a case in point. Countries highly dependent on oil or other natural resources performed very poorly since 1980 . Figure 1 shows GDP per capita at purchasing power parity for highly resourceintensive countries such as Saudi Arabia, Nigeria, Venezuela and Zaire, and for less intensive countries such as Indonesia and Mexico. The pattern is clear, the more dependent performed remarkably poorly. The less oil-dependent did better. The concern that natural resource wealth may somehow be inmiserating is a recurring theme in both policy discussions and in empirical analysis. The empirical regularity seems to be in the data ${ }^{1}$ but understanding its causes has been a much harder task ${ }^{2}$. Theorists have been hard at work to find a rationale. Is it a consequence of the Dutch Disease? Is it caused by the volatility that characterizes resource-based commodity prices? Is it due to political economy forces unleashed by the presence of rents? And what are the policy implications of this problem?

\footnotetext{
${ }^{1}$ For example, Sachs and Warner (1995) estimated that countries fully dependent on the export of primary products grew about 2.5 percent per year more slowly in the 1970-1989 period. Gavin and Hausmann (1998) and Higgins and Williamson (1999) find a strong relationship between resource intensity and inequality.

${ }^{2}$ For example, Manzano and Rigobon (2001) attribute the low growth to a debt overhang associated with over borrowing during the boom of the 1970s.
} 
Is there such a thing as having too much oil for the country's own good? Should oil income be saved in net terms? Or is the question mainly that of dealing with the volatility in the flows? Are other policies called for?

In this paper we will propose an alternative rationale for the resource curse and discuss some of its policy implications. The approach is based on the interaction between two building blocks: specialization of the domestic economy in the production of non-tradables and financial market imperfections. We show that as an oil economy becomes more specialized in the production of non-tradables, the real exchange rate becomes more volatile because shocks to the demand for nontradables -associated for example with the fiscal expenditure of shocks to resource income - will not be accommodated by movements in the allocation of capital and labor but instead by expenditure-switching. This requires much larger relative price movements. Financial frictions such as risk aversion or costly bankruptcy on corporate debt implies that the interest rate will be a function of the volatility in the economy. In fact, the volatility of profits in the non-resource tradable sector can be shown to be larger than in the non-tradable sector. As volatility increases, sector-specific interest rates rise causing a decline in the output that is larger for the non-resource tradable sector. A multiplier process is set in motion where an initial rise in interest rates causes the tradable sector to contract, further raising volatility and interest rates until the sector disappears. At 
that point, the economy will face an even higher interest rate and a lower level of capital and output in the non-tradable sector. An increase in resource income that leads to specialization causes a large decline in welfare: thus the idea of the curse. This form of specialization is inefficient and is characterized by high volatility and interest rates, weak real exchange rates, low wages and investment. Inefficient specialization is determined by the level and the volatility of resource income and by the international interest rate. The paper discusses the role of fiscal saving of oil revenues as well as stabilization of expenditures. In addition, independent policies that reduce country risk and that improve the functioning of financial markets are seen as being particularly important in this context. More interventionist policies to subsidize investment in the non-resource tradable sector may also have a role to play.

The paper is organized as follows. Section 1 summarizes and criticizes the previous literature on the resource curse. It also presents the logic of our approach in informal terms. Section 3 presents the formal model and analyzes its properties. Section 4 discusses the policy implications..

\section{Previous approaches to the resource curse}

There have been several approaches in the literature to account for the resource curse. The first is associated with the notion of the Dutch Disease. The second has 
to do with the rent-seeking activities generated around the presence of the associated tax revenue. The third approach has to do with the damaging effects of volatility. In this section we will discuss each of these theories and their limitations.

\section{A. The Dutch Disease Approach}

Increases in resource-based revenues, such as oil, generate a greater capacity to import tradables, but typically prompt a greater demand for all goods including non-tradables, which cannot be imported but must be produced locally. This requires the economy to move resources out of the non-resource tradable sectorcall it manufacturing - in order to expand the production of non-tradables such as construction and services. An oil boom would lead to a contraction in manufacturing. A real appreciation is the mechanism that gets the job done (Corden, 1982, Corden and Neary, 1984). This is the Dutch disease.

This logic is compelling, but by itself it does not imply any inefficiency or welfare loss. It only states that booms in resource income would be associated with contractions in manufacturing, not in overall growth. It cannot explain why a country would grow more slowly, just because it has oil.

To get some mileage, one has to assume that non-resource tradables play a special role in the growth process. This is the tradition started by Matsuyama (1992) 
where he assumed that there are increasing returns to scale in manufacturing, but not in the resource sector. Hence, an abundance of the natural resource makes the economy specialize in the less dynamic sector ${ }^{3}$. Hence, this may explain the curse.

One problem with this explanation is that one should expect that over the long run oil-exporting countries would be doing poorly when oil is doing well and that they would be improving when oil becomes less dynamic. However, over the 60 year period between the early 20 s and the early 80 s Venezuela was the country with the highest growth in per capita income out of the 40 countries for which Maddison (1992) has data. During the following 20 years, Venezuela is among the worst performers in the world, a period which coincides with the decline of its oil income (Hausmann, 2002). This is not just a coincidence. The same pattern can be observed if we look at the growth rate of a wider group of countries over a shorter period. As Table 1 shows, oil-exporting countries grew faster in the period of rising oil prices and volumes between 1960 and 1980 relative to other developing countries and collapsed when oil revenues declined after 1980. If the Dutch Disease story was right, the post-1980 story should have been one of greater growth. Hence, the story as such does not fit the facts.

\footnotetext{
${ }^{3}$ Alternatively, it may want to diversify into resource-intensive industrialization, which has failed in many countries, Auty (1990)
} 
Table 1. Average annual growth in per capita GDP at purchasing power prices

\begin{tabular}{|l|r|r|r|r|}
\hline Country group & $1960-1998$ & $1960-1980$ & $1980-1998$ & $\begin{array}{r}\text { Number of } \\
\text { countries }\end{array}$ \\
\hline All developing & 1.7 & 3 & 0.2 & 115 \\
\hline - oil exporters & 1.1 & 5.2 & -2.1 & 15 \\
\hline - others & 1.8 & 2.7 & 0.5 & 100 \\
\hline
\end{tabular}

Source: World Penn Tables, own calculations

Moreover, it is not obvious that learning by doing or technological development is slower in resource based industries relative to others. As the World Bank (2001) has shown in a recent report, several industrial countries such as Australia, Canada and Finland became rich by developing the technology and capital goods industries associated with their resource sectors. Moreover, whatever bad effects specializing in natural resources might generate they have to be compared with the benefits of owning large natural resources.

For example, natural resource income may raise national savings and hence facilitate capital accumulation and growth. This is not a minor aspect as oil exporting economies have averaged twice the savings rate of non-oil exporters (Table 2). Moreover, they were able to save more and grow more in the period when oil was growing fast (1960-1980) relative to the more recent episode (19801998). 
Table 2. Average domestic savings rate

\begin{tabular}{|l|r|r|r|r|}
\hline $\begin{array}{l}\text { Country } \\
\text { group }\end{array}$ & $1960-1998$ & $1960-1980$ & $1980-1998$ & $\begin{array}{r}\text { Number of } \\
\text { countries }\end{array}$ \\
\hline $\begin{array}{l}\text { All } \\
\text { developing }\end{array}$ & 17.1 & 18.4 & 16.2 & 111 \\
\hline - oil & 33.2 & 37.9 & 30.1 & 15 \\
exporters & 14.6 & 15.3 & 14 & 96 \\
\hline - others & & & & \\
\hline
\end{tabular}

Source: World Penn Tables, own calculations

\section{B. The Rent-Seeking Story}

An alternative story is that resource wealth such as oil somehow makes societies less entrepreneurial. There is so much wealth floating around the government that entrepreneurial persons find it much more profitable to engage in unproductive rent-seeking activities to appropriate that wealth rather than in creating more wealth. The presence of common-pool problems or uncertainty over property rights over the resource income may generate low growth by inefficiently focusing economies in fighting over existing resources.

The common-pool problem - caused by situations where costs are shared between many agents but benefits are private (e.g. as in fiscal policy) - may lead to overspending on average and to a distorted allocation of spending over time. Overspending is associated with the idea that different constituencies do not 
internalize the full cost of their spending requests, as they only pay a small fraction of the additional tax burden. (Weingast, Shepsle and Johnsen, 1981, von Hagen and Harden, 1994). This problem is not specific to resource rich economies, but instead is present in all countries. However, in resource rich economies, where non-resource taxes are typically low and resource rents are large, it could be argued that this force could in theory be more powerful.

In a dynamic setting this logic may lead to overborrowing and to a voracity effect (Hausmann, Powell and Rigobon, 1990, Velasco, 1995, Lane and Tornell , 1999). Assume that it is best to save a temporary boom until some future time when lower resource income is expected. An individual would choose to smooth consumption. However, when there is a common-pool problem each constituency will ask for a larger share of the pie in good times, fearing that if they don't, other constituencies might take it away.

This story again does not explain why oil economies did so well when incomes were rising and why they have under performed so strongly in the last two decades.

In yet a different setting, others have argued (Karl 1997) that oil economies, by not developing the political compact that allows the State to tax its citizens are 
poorly equipped to deal with collapses in oil revenues without leading to macroeconomic crises.

This logic may be present, but other factors may well overwhelm it. We already mentioned the fact that resource revenue may allow for higher savings. It may also allow the country to reduce taxation over more mobile factors and hence achieve a less distortionary overall taxation scheme, thus generating a more propitious economic environment for growth. Moreover, the political skills required to allocate rents among different groups may be useful in achieving the necessary reallocations when income declines.

\section{The volatility story}

An alternative explanation to the curse puts the emphasis on volatility. Volatility has been shown to be bad for growth, for investment, for income distribution, for poverty and for educational attainment ${ }^{4}$. Natural resource rents tend to be very volatile because the supply of natural resources exhibits low price-elasticities of supply. For example, the standard deviation of oil price changes has been about 30 to 35 percent per year. For a country where oil represents about 20 percent of

\footnotetext{
${ }^{4}$ See IDB (1995), Gavin and Hausmann (1996), Ramey and Ramey (1995), Aizenman and Marion (1999), Caballero (2000). Flug et al (1996) and Duryea (1998) discuss the impact of volatility on educational attainment.
} 
GDP, a 1 standard deviation shock to the price of oil represents an income shock equivalent to 6 percent of GDP. This is huge relative to total GDP volatilities in industrial countries (about 2 percent) or even developing countries (between 3 and 4 percent).

But how does volatility in the terms of trade damage the economy? Assume that resource revenues are distributed to the population as a whole, say through government transfers. This means that the fact that the revenue is volatile makes it less valuable to risk-averse consumers. Let us take a relatively severe example. Assume that in a given economy oil is 30 percent of national income and that it has a standard deviation of about 30 percent per year. Assume that utility can be described with a constant relative risk aversion (CRRA) utility function with a relatively high coefficient of risk aversion of 3 . This implies that consumers would be willing to sacrifice 4.05 percent of national income in order to make oil revenues perfectly certain. They would be willing to spend that much money in hedging their resource risk: certainly more than a simple nuisance, but nothing that could reasonably be called a curse, when compared with the revenue it generates. This could reasonably justify organizing a seminar to discuss how governments should manage this risk, but is not an adequate explanation for the massive collapse in growth exhibited in Figure 1. 
So the welfare losses associated with the consumption risk of the flow itself are not particularly large. To get bigger effects, the rest of the economy must somehow be disrupted by the volatility in oil. Interestingly, in a neo-classical setting, it is quite hard to make volatility matter. Imagine first a competitive economy in which capital is perfectly mobile internationally and labor is nationally fixed, but is perfectly mobile domestically across sectors. Assume that there are three sectors: a resource sector - which we will call oil; a tradable sector and a non-tradable sector. Oil is produced without either capital or labor: it is like manna from heaven. One can also think of it as aid. The two other sectors are produced with capital and labor and exhibit constant returns to scale. In this case, so long as all goods are produced domestically, the volatility of the oil sector will not affect the value of non-oil output or any non-oil relative price. The income of workers and the rate of return to capital in the non-oil economy will be unaffected by oil volatility!. Hence, the only problem will be the dislike for oil volatility itself and this we have already found not to be too serious.

To understand this surprising result it is important to remember that there are five prices in this economy. First, the price of oil is determined abroad. Second, the rate of return to capital will be set by the world interest rate, given perfect capital mobility. Third, the price of tradables will be set internationally through the law of one price. Fourth, the internationally determined price of tradables and cost of 
capital together with the zero-profit condition required by perfect competition will set the wage that the tradable sector can pay, which will determine, through the free movement of workers between sectors, the wage rate for the whole economy. Fifth, this will determine non-tradable prices since wages and the cost of capital are already set and profits must be zero. Shocks to the demand of non-tradables (induced possibly by oil shocks) will be adjusted through movements of labor between sectors and movements of capital in and out of the economy. The production possibility frontier will be completely flat as shown in Figure 2.

We find this to be a very important benchmark not because it is an adequate description of the world, but because it provides a point of departure to think of the possible characteristics of the world - not included in the benchmark - that may explain why oil and its volatility may become really problematic.

With full employment, and set wages and returns to capital, non-oil income will be stable. The only source of volatility will be the direct impact of oil revenues in household income. As we mentioned above, the welfare losses associated with this uncertainty are not huge: a nuisance more than a curse. To get to explain a curse the non-oil economy must be more seriously disturbed by oil volatility.

What features of the world does our benchmark not take into account? First, capital takes time to build and once invested is usually irreversible. It cannot 
move instantaneously between sectors. This is certainly a problem. It means that the production function will be convex and that the volatility on government spending will cause shifts in relative prices. However, the consequences of this are not as serious as one might think. In a standard model, profits are a convex function of relative prices (Caballero 1991). This means that the greater the volatility in relative prices the larger will be the expected profits and average investment! Moreover, if we assume full employment, the welfare of workers may actually go up and not down with volatility, since they would be working on average with more capital. Hence, irreversibility of investment cannot be the basis for a serious curse.

Second, consider the presence of price and wage rigidities that prevent the labor market from clearing. In this case, and assuming that capital is pre-determined and irreversible ${ }^{5}$, volatility in oil income and government spending will translate into changes in unemployment and output in the non-tradable sector. Notice, however, that the tradable sector will remain unaffected: it will face constant prices, wages and stock of capital. Therefore employment and output will be constant. The non-tradable sector will have constant capital and wages but volatile output. It will also have more capital invested in the non-tradable sector than in

\footnotetext{
${ }^{5}$ In makes sense to assume that if prices cannot be readjusted, that capital should be even harder to adjust.
} 
our benchmark, given the convexity of the profit function. Welfare losses caused by oil volatility are likely to be larger, because volatility is larger, but the expected average levels of output and consumption should not be much affected.

\section{Our approach}

So where can the curse come from? We will argue that it will arise from an interaction between specialization and financial market imperfections. In the benchmark model we assumed that the economy was producing all goods. What happens if the non-oil economy stops producing tradables and becomes completely specialized in non-tradables? Central to the results of the benchmark model is the requirement that there be a positive level of production of tradables: the non-oil economy must not be fully specialized in non-tradables. This allows labor movements between sectors to absorb the shocks to non-tradable demand. If the economy were fully specialized in non-tradables, this result would disappear (Figure 3). Labor would now be fixed and fully employed in non-tradables. The only way to expand supply would be by increasing the amount of capital per worker in the sector. But capital is required to get the international rate of return. However, with labor fixed, the productivity of each additional unit of capital would be falling. To avoid returns to capital to fall, the price of non-tradables must go up. Hence, the supply of non-tradables will now be upward sloping. But the demand for non-tradables must be downward sloping. An increase in the price 
of non-tradables will cause expenditure-switching effects, as consumers will substitute away from the now more expensive non-tradables and into tradables. The relative price between these two goods, i.e. the real exchange rate will have to move in order to clear the market for non-tradables.

So, in our benchmark model, a specialized economy with volatile resource revenue will see a volatile real exchange rate, while a diversified economy will have a constant real exchange rate. In this setting, irreversibility in capital will make relative prices even more volatile, as now the supply of non-tradables would be completely pre-determined, given that both labor and capital will be fixed. Only expenditure-switching forces will be at play. This will make the real exchange rate even more volatile.

We will show below that this still is not enough to generate a real curse. In this paper we will propose a form of financial imperfection that will cause interest rates to be sensitive to the volatility in the real exchange rate. In particular, we will assume that only debt contracts are available and that bankruptcy is costly. This will make interest rates go up as the volatility of the real exchange rate increases. There is a vicious circle between greater volatility and interests rates on the one hand and lower investment in tradables on the other. The interest by the tradable sector increases until the sector disappears and the economy specializes inefficiently in non-tradables. The specialized economy will exhibit higher 
interest rates on nonn-tradables, lower capital and wages and a more depreciated exchange rate.

\section{Modeling the curse}

In this section we offer a formal model of the inefficient specialization. The ingredients of the model are the following: Assume there are three sectors in the economy, tradables, non-tradables and oil. Oil is assumed to consume no inputs and generates a stochastic stream of revenues denominated in tradables. We assume it is exogenous and denoted by $\widetilde{g} L$.

The tradable and non-tradable sector are comprised of a finite number of firms, each using one unit of capital and producing output according to

$$
y_{N}=l_{N}^{1-\alpha}
$$

in the non-tradable sector, and

$$
y_{T}=l_{T}^{1-\alpha}
$$

in the tradable sector.

We assume that capital is owned by foreigners. This simplifies the analysis as it allows us to disregard the effect of changes in capital income. Furthermore, the 
results are unaffected (qualitatively speaking) by assuming that domestic agents own some capital. We will assume that capital is irreversible and that it has to be decided one period before production and oil revenues are realized.

We assume that oil belongs to the government, which consumes it entirely in nontradable goods. If the government decides to save its oil revenue, it will do so in foreign assets. We will assume that households derive no utility out of government consumption. This means that the volatile government consumption will not enter directly into the utility of risk-averse households who might want to smooth it. This eliminates the standard justification for stabilization. As discussed above, this cannot possibly be the source of the curse if there is one. We assume that there are no taxes.

Finally, we assume that capital is fully depreciated in one period and that consumers cannot save. Thus, in this regard, the model is equivalent to a single period model. Consumers have a standard Cobb-Douglas utility function, with equal weights on tradable and non-tradable goods, and the share of non-tradables is $\beta$. 


\section{Production}

We assume that firms are small (price takers). We assume there are $N_{N}$ firms in the non-tradable sector. Each firm requires an investment of one unit of capital to operate, and each production function is given by

$$
y_{N}=l_{N}^{1-\alpha}
$$

Optimal labor decisions conditional on the capital invested in the non-tradable sector solves

$$
\max P_{N} l_{N}^{1-\alpha}-w l_{N}
$$

where $P_{N}$ and $w$ are the price of non-tradable goods and wages in domestic currency respectively. The solution implies that labor demand is

$$
l_{N}=\left[(1-\alpha) \frac{P_{N}}{w}\right]^{\frac{1}{\alpha}}
$$

production is

$$
y_{N}=\left[(1-\alpha) \frac{P_{N}}{w}\right]^{\frac{1-\alpha}{\alpha}}
$$


and profits in the sector in domestic currency are

$$
\pi_{N}=\frac{\alpha}{1-\alpha} w\left[(1-\alpha) \frac{P_{N}}{w}\right]^{\frac{1}{\alpha}}
$$

The tradable sector is the same. There are $N_{T}$ firms, were, again, each firm requires one unit of capital. We have assumed that the capital share is the same in both sectors. Hence,

$$
l_{T}=\left[(1-\alpha) \frac{e}{w}\right]^{\frac{1}{\alpha}}
$$

where $e$ is the exchange rate. Production is

$$
y_{T}=\left[(1-\alpha) \frac{e}{w}\right]^{\frac{1-\alpha}{\alpha}}
$$

and profits in the sector in domestic currency are

$$
\pi_{T}=\frac{\alpha}{1-\alpha} w\left[(1-\alpha) \frac{e}{w}\right]^{\frac{1}{\alpha}}
$$




\section{Government}

We assume that oil exports are in dollars. Hence, the total government consumption of non-tradable goods is

$$
\frac{e}{P_{N}} \tilde{g} L
$$

In this simple setup we are assuming that the government does not face any financial frictions. In other words, the cost of financing is the same as the benefits of saving.

\section{Demand}

Households consume tradable and non-tradable goods, but not oil. There are no taxes. We assume that consumers' utility can be represented by the standard Cobb-Douglas utility function. Furthermore, to simplify the number of parameters under study, we assume that the weights are the same.

Assume the consumers solve

$$
\begin{aligned}
& \max C_{T}^{1-\beta} C_{N}^{\beta} \\
& \text { st. } e C_{T}+P_{N} C_{N} \leq W
\end{aligned}
$$


where $C_{T}, C_{N}$, and $W$ are the consumption in tradables, consumption of non tradables, and wealth of consumers, respectively. The FOC of the maximization problem implies the standard solution. Given our assumption that the capital is owned by foreigners, then comsumer's wealth is given by total labor income.

$$
C_{N}=\beta L \frac{w}{P_{N}}
$$

\section{Equilibrium}

Conditional on the amount of capital in the non-tradable sector let us compute the labor market equilibrium

$$
\begin{aligned}
& L_{T}+L_{N}=L \\
& L_{T}=N_{T} l_{T} \\
& L_{N}=N_{N} l_{N}
\end{aligned}
$$

and the non-tradable goods market equilibrium in our benchmark model:

$$
C_{N}+\frac{e}{P_{N}} \widetilde{g} L=Y_{N}
$$

Substituting, the two equations solving for equilibrium are

$$
N_{N}\left[(1-\alpha) \frac{P_{N}}{w}\right]^{1 / \alpha}+N_{T}\left[(1-\alpha) \frac{e}{w}\right]^{1 / \alpha}=L
$$




$$
\beta L \frac{w}{P_{N}}+\frac{e}{P_{N}} \tilde{g} L=N_{N}\left[(1-\alpha) \frac{P_{N}}{w}\right]^{\frac{1-\alpha}{\alpha}}
$$

Define,

$$
\begin{aligned}
& q=\frac{P_{N}}{w} \\
& Q=\frac{e}{P_{N}}
\end{aligned}
$$

This implies that the two equations collapse to:

$$
\begin{gathered}
N_{N}+N_{T} Q^{1 / \alpha}=L[(1-\alpha) q]^{-1 / \alpha} \\
\frac{N_{N}}{N_{N}+N_{T} Q^{1 / \alpha}}=(1-\alpha) \beta+(1-\alpha) q Q \widetilde{g}
\end{gathered}
$$

Note that the total number of firms must be grater than zero. Note also that it is impossible to find a set of parameters in which the number of non-tradable firms is zero. However, there exist a set of coefficients where the number of tradable firms indeed is zero. For those circumstances, the set of equations determining the equilibrium in the labor market and the non-tradable goods market are identical to the previous ones but with $N_{T}$ equal to zero. 
After some algebra these two equations collapse to the following relationship

$$
\begin{aligned}
& {[1-(1-\alpha) \beta-\Psi]\left(\frac{N_{T}}{L}\right)^{\alpha}=\Psi^{\alpha} \widetilde{g}} \\
& \Psi=\frac{N_{N}}{N_{N}+N_{T} Q^{1 / \alpha}}
\end{aligned}
$$

Hence, assume the number of firms in the non-tradable sector is fixed, this equation uniquely defines the solution for the number of tradable firms in equilibrium. Lets study the equilibrium in Figure 4.

The downward slopping line corresponds to the LHS of the equation, and the increasing concave schedule is the RHS. Notice that all the uncertainty of oil expenditures appears on the RHS. Hence, we have depicted three schedules reflecting the (supposedly) maximum, median and minimum of the shocks.

As can be seen, the two schedules determine (uniquely) the real exchange rate at which both equilibrium conditions are satisfied. Note that for each realization of the oil price there is a corresponding RER.

In the figure, we have depicted an increase in the number of tradable firms. This makes the LHS line steeper. For a given level of uncertainty, this implies an increase in the expected value of $\Psi$, and a reduction in its variance. Since $\Psi$ is an inverse function of the RER, we conclude that a larger tradable sector requires a 
more depreciated exchange rate, but delivers a more stable RER for the same degree of oil-related uncertainty.

This is an important characteristic of the model and it is useful to understand what drives it. When the number of tradable firms is large (small), reductions in the demand for non-tradables can be accommodated through an expansion in the output of tradables with a relatively small (large) decline in the real wage, since the high (low) stock of capital per potential worker invested in tradable production implies that the marginal product of labor declines little (a lot) for every additional worker. In the limit, if there is no capital invested in the tradable sector, there will be no employment in the sector and the adjustment will take place exclusively through the expenditure switching implications of real exchange rate movements. This fact will become important below when we endogenize the number of firms.

\section{Irreversible Capital and Financial Frictions}

The final ingredients of the model relate to the investment decision, which in this setup is equivalent to the number of firms in each sector. As was mentioned before, foreigners own the capital in both sectors. They have to decide the number of firms that will operate in each sector before the government expenditure is 
realized. Hence, if investors are risk neutral, the entry condition for the nontradable sector is:

$$
E\left\{\frac{\alpha}{\theta}[(1-\alpha) q]^{1-\alpha} \alpha\right\} \rho
$$

and for the tradable sector is

$$
E\left\{\alpha\left[(1-\alpha)_{q} \theta\right]^{\frac{1-\alpha}{\alpha}}\right\} \geq \rho
$$

where $E$ is the expectation operator. Substituting the solutions for the RER we have that the stochastic profits in each of the sectors are:

$$
\begin{gathered}
\tilde{\pi}_{N}=\alpha L^{1-\alpha} \frac{N_{N}}{N_{T}^{\alpha}} \frac{\Psi}{(1-\Psi)^{\alpha}}-\rho \\
\tilde{\pi}_{T}=\alpha L^{1-\alpha} \frac{1}{N_{T}^{1-\alpha}}(1-\Psi)^{1-\alpha}-\rho
\end{gathered}
$$

Now, we introduce financial frictions in the model by appealing to risk aversion. However, the results presented in the paper would be the same if instead of risk aversion, we had assumed costly bankruptcy. 
Firms require a rate of return that must compensate them for the volatility of profits. The rate of return will be proportional to their degree of risk aversion $\sigma$. Assume that the entry condition is given by

$$
\Pi_{i}=\frac{\left(\widetilde{\pi}_{i}\right)^{1-\sigma}}{1-\sigma}
$$

for each sector.

Notice that the profits of the tradable sector inherit the stochastic properties of $\Psi$. Indeed, the variance is proportional to the variance of $\Psi$. Similarly for the nontradable sector. Implicitly the degree of risk aversion implies that the expected return has to be equal to the risk free rate plus $\sigma$ times the variance of the profits. When the number of tradable firms increases the value of $\Psi$ increases (diminishing the expected profit) but reducing its variance. Notice that this movement is always positive in the non-tradable sector. An increase in the number of tradable firms increases the expected value of $\Psi$, increasing the expected value of the profits, and reducing the volatility of $\Psi$, reducing further the risk premium. 


\section{Simulation}

In this section we simulate numerically the model in order to understand the implications of changes in the size of the oil revenues, its volatility and degree of risk aversion on the economy. In particular, we will study their effect on the number of firms in each sector, the utility of households and the volatility of the real exchange rate. The parameters chosen for the simulation are as follows. The economy has a size of $L=1$. We assume that the rate of return required is equal to 5 percent. We set $\alpha$ equal to 0.25 and not the more common $0.3 \sim 0.4$ because in this model, capital is composed of tradable goods. In real life, capital also has non-tradable components. However, assuming a demand for non-tradables for investment purposes would have complicated the model unnecessarily.

We let the mean level of oil income move from 0.1 to 0.8 . We assume that it is uniformly distributed with a coefficient of variation of zero, $0.25,0.75$ and 0.875 . We present our results for two cases: a risk neutral case $(\sigma=0$, which we interpret as no-financial frictions) and an alternative case with a relatively large degree of risk aversion $(\sigma=15)$.

In each figure the $\mathrm{x}$-axis indicates the mean level of the oil income. Each figure has four panels: the top panel is the number of non-tradable firms in equilibrium, the second one is the number of tradable firms, the third is the utility of 
consumption and the final panel is the volatility of the real exchange rate. In each panel we represent four curves representing the four degrees of volatility mentioned above, where the thicker lines represent greater volatilities.

Lets study first the risk neutral case (Figure 5). As the mean level of oil income increases, the number of firms in the non-tradable sector rises and the number in the tradable sector declines. The economy monotonically tends to specialize away from tradables, as would be predicted from the standard Dutch Disease literature. Notice that utility is little affected by the level of oil income. Recall that we assume that the government spends the oil revenue in non-tradable goods that households do not value and that capital is foreign owned. Hence, the utility of households is determined by the real wage and this does not change with oil income.

Volatility in this setup has surprising effects: it increases the number of firms in the tradable sector, lowers the number of firms in the non-tradable sector and increases utility! This contradicts the conventional wisdom, which suggests that the increase in uncertainty should be bad for investment, especially if it is irreversible. This intuition does not hold in this model, a feature amply discussed in the neoclassical literature (See Hartman, 1972, Caballero, 1991, Caballero and Pindyck, 1996). The main reason for this effect is the fact that the profits of tradable firms are a convex function of $\Psi$. This means that greater volatility 
increases expected profits and investment in tradables. On the other hand, the profits in the non-tradable sector can be concave or convex in $\Psi$ and hence the volatility will have less salutary effects. For the parameters in this model the function is concave and the number of non-tradable firms falls with volatility ${ }^{6}$. Utility increases because wages are also convex in $\Psi$. Interestingly, specialization in this model is not associated with volatility but instead solely with the average level of oil income. Hence, policies geared at stabilization are not welfare improving.

We now turn to the case with risk aversion (Figure 6). We assume a level of risk aversion of 15 , which is high by conventional standards but significantly less than the coefficient of 40 required to explain the equity premium in developed countries. Remember that we take risk aversion to be a proxi for financial frictions in the economy.

Here we observe a similar initial impact of increases in the mean level of oil income on the number of firms in both sectors. However, notice that now volatility lowers the number of firms in both sectors, as investors demand a higher return to compensate for the greater variance in their returns, overwhelming the

\footnotetext{
${ }^{6}$ In fact, for most reasonable set of parameters the schedule is concave. The relationship becomes convex when the number of non-tradable firms approaches zero.
} 
otherwise convex relationship of profits on $\Psi$. There is a point at which the tradable sector completely shuts down. We refer to this phenomenon as inefficient specialization. At that point, the number of firms in the non-tradable sector also declines (and then rises very gradually), the volatility of the real exchange rate increases by a factor of more than 10 and utility collapses.

The mechanism that brings this about is a vicious circle between specialization and volatility. Remember that the volatility of the real exchange rate and $\Psi$ is inversely proportional to the number of firms in tradables. As the number declines profits become more volatile, but risk aversion requires now a higher risk premium, which lowers investment in tradables further and further increases volatility. The sector disappears because the cost of capital makes expected firm profits negative. This happens only in the tradable sector because its price is exogenously set. In the non-tradable sector, the increase in risk premia lowers investment, but this increases the price of non-tradables, preserving profitability.

The decline in utility is related to the magnitude of the inefficiency of the specialization. A measure of this inefficiency is the difference between the number of tradable firms in the zero volatility curve and the actual number of firms. Notice that as the average level of oil income increases, the economy would naturally specialize and hence the gap between the efficient number of firms and the actual number declines. Hence, utility recovers, but does not reach 
the no volatility level because the absence of the tradable sector makes the real exchange rate more volatile and hence lowers the investment in non-tradables, where the number of forms also falls relative to the optimal level.

This result might help explain why countries that were very specialized in oil production such as Saudi Arabia, Nigeria and Venezuela fared so poorly when oil income declined while countries such as Indonesia, Mexico and Norway were much less affected. The first group was specialized in oil and when oil income declined that specialization became much more inefficient, while the lack of a tradable sector created a level of volatility and risk premia that did not allow for investment. Diversified countries could adjust with much smaller costs.

In conclusion, (i) specialization in the production of non-tradables creates an economy with more volatile relative prices. (ii) financial frictions interact with this volatility further specializing the economy as the stock of capital will respond to the greater macroeconomic volatility. (iii) this specialization may lead to the complete and inefficient disappearance of tradable production. (iv) this specialization reduces the investment in non-tradables - which will face a larger cost of capital - and lowers welfare. 
Clearly, in this context, a higher level of oil revenues can become a curse if it leads the economy to inefficiently specialize. Moreover, stabilization policies can have large welfare implications.

\section{III.Policy implications}

The curse of natural resources has so far been explained as being caused by either rent-seeking or diversification away from sectors enjoying increasing returns. Separately, expenditure stabilization policies have been advocated based on the welfare benefits of consumption smoothing. In this paper we have proposed an alternative mechanism for the curse that integrates it with the discussion of stabilization.

We point out that an economy that is diversified, in terms of having a significant non-oil tradable sector, will be much less affected by volatility in government domestic spending than an economy that is already fully specialized in nontradables. This is so because in a diversified economy shocks to non-tradable demand can be accommodated through changes in the structure of production while specialized economies have to rely on expenditure switching. We note that countries with more resource rents will naturally produce fewer tradables and hence are more likely to be naturally specialized. 
However, the presence of quite standard financial frictions, such as costly bankruptcy, will make relative price volatility affect the cost of capital through risk premia. This has three major consequences: first, it causes the economy to specialize further by making it harder and in some cases impossible for the tradable sector to access capital; second, it causes higher interest rate and less capital in the non-tradable sector under specialization; third, it greatly increases the welfare losses caused by volatility.

The policy implications of this model are relatively straightforward. They have to do with avoiding inefficient specialization, and reducing the costs of volatility. We separate our discussion in two parts. First we deal with first-best policies, which are based on reducing the distortions in the economy. Then we move to second-best policies, where we assume that the distortions are hard to remove and look at interventions that can improve welfare, given that the distortions make the market outcome inefficient. This is in general the spirit of the policies we are discussing below.

\section{A. Fiscal policy}

To discuss fiscal policy it is important to separate between three types of countries: 
- Those that are naturally specialized, i.e. those that would specialize even in the absence of volatility.

- Those that are inefficiently specialized

- Those that are not specialized and would like to stay that way

\section{Naturally Specialized Countries}

These countries have so much natural resource wealth that it does not make sense for them to engage in the production of other tradables, even in a first-best world. Some Gulf states might be in this category. However, in these countries, specialization makes relative prices very sensitive to the volatility in government spending. These countries would benefit from policies that stabilize government expenditures in order not to transmit volatility to the domestic market.

\section{Inefficiently Specialized Countries}

These countries are suffering from major welfare losses associated with the inability to develop the tradable sector, which makes the cost of capital high, even for non-tradable sector. Countries such as Venezuela and Nigeria may be in this category. Inefficient specialization is the product of a combination of factors: the level of government spending, the volatility of that spending, the "commercialrisk-free" interest rate to which firms in the economy have access and the magnitude of financial inefficiencies. 
These countries need to make a big effort to change the structure of the economy sufficiently to get it over the specialization frontier. Incremental changes may not be enough to improve matters significantly. There are three fiscal margins in which these economies could work: the average level of government spending, its volatility and the "commercial-risk-free" interest rate.

With respect to the first point, it is useful to be precise in what we call "government spending" in the context of our model. We assumed that there was no domestic taxation. In a world with taxes, the relevant policy variable is the primary deficit excluding oil revenues and external spending by the government. This variable must be credibly lowered and stabilized in order to cross the specialization frontier. There is some trade-off between lowering the average and lowering its volatility. The more credible the reduction in volatility, the less important will be the required reduction in average spending. However, our simulations suggest that, for the parameters we studied, feasible cuts in average spending seem quantitatively more effective than feasible reductions in volatility, although the latter bring greater improvements in welfare. Hence, an ideal policy would rely on both. Hence, stabilization per se would not be enough: cuts in the structural non-oil primary deficit would be called for.

Furthermore, fiscal policy and debt management policies have an important role to play in affecting the interest rate. In our model we assumed a riskless 
international interest rate to which we added the commercial risks faced by each sector. In real life, on top of this commercial risk there may be country risk, associated with fears about the sustainability of public debt and of the government's fiscal position. Factors that increase country risk will have the effect of moving the specialization frontier in: the economy will specialize at lower average levels of spending and at lower volatilities.

Country risk often rises because of concerns about willingness to pay, or because the budget institutions are perceived as not capable of imposing an effective budget constraint. Also, poor debt management can inefficiently expose a country to roll over risks or other problems and thus increase country risk. These problems should be avoided by any country. However, resource rich countries are at risk of suffering heavily because the higher interest rate these problems cause may inefficiently keep them specialized in a low income - high volatility environment.

It is important to stress that countries in this category become specialized, not because wages in dollars are too high. In fact, if they are able to move to the world of diversification, capital intensity will rise and workers wages will increase. Moving to a diversified economy is welfare enhancing; it does not imply real wage cuts. 


\section{Diversified Economies}

Economies in this category are characterized by having large non-resource tradable sectors. Examples in this category are countries such as Ecuador, Mexico or Indonesia. In these countries, volatility in oil revenues will have smaller effects on relative prices, provided that they have relatively flexible domestic markets ${ }^{7}$. Hence, the benefits of stabilization ceteris paribus are likely to be smaller than in the other two cases. However, these economies run the risk of becoming specialized if they increase the average non-oil primary deficit, its volatility or have high country risk. For example, Indonesia has seen a big increase in country risk, while Ecuador is undergoing a big expansion in oil production in the context of very high country risk. Here the role of fiscal policy is to keep the economy diversified. It is mainly a preventive strategy that is called for.

\section{B. First-Best Financial Policies}

In our framework, the inefficient disappearance of the non-oil tradable sector is a consequence of financial frictions. Policies that minimize these frictions will allow the financial market to better manage the risks faced by the tradable sector and hence to displace the specialization frontier and to offer financing at lower

\footnotetext{
${ }^{7}$ After all, in our model we assumed sufficient labor mobility to clear the labor market.
} 
cost, when the sector exists. We shall start with a list of first best policies. Later, we will discuss some more interventionist policies.

Policies that complete financial markets by expanding the space for credible contracts will have particularly powerful effects on countries that are inefficiently specialized. These include:

- Policies that make contract enforcement less costly, through effective judicial enforcement and extra-judicial conflict resolution

- Policies that contain willingness-to-pay problems in financial markets such as facilitating the use and effectiveness of collateral - Policies that efficiently reduce the cost of bankruptcy

In addition, the high volatility that characterizes resource rich economies are bound to make equity particularly valuable, as it allows better risk sharing between firms and investors. This agenda calls for:

- Policies that facilitate direct investment, especially in the non-resource sector

- Policies to improve corporate governance so as to make equity claims more credible 


\section{Second Best Policies}

While first-best policies are good for all countries, they are particularly important valuable for inefficiently specialized economies. However, this inefficiency might also be addresses through second best policies, i.e. policies that assume that it is hard to credibly avoid fiscal spending volatility or financial frictions. What policies could improve welfare in such a context?

The central problem with the inefficiency we describe is that the tradable sector is starved out of capital because it faces too high a real exchange rate volatility for debt markets to manage. Second best policies involve in one way or the other the need to stabilize the profits of the tradable sector. We discuss two main forms of intervention: trade policies and financial policies.

\section{Trade policies}

If the tradable sector disappears because of unstable expected profits, what role could trade policy play? Let us consider state-contingent protection composed of export subsidies and import tariffs that would go up in times of real appreciation and would be lowered in periods of real depreciation. The idea is that with a more stable expected profit, the sector could attract more capital. In "good times" when oil is high and the real exchange rate is appreciated, export subsidies and import tariffs would kick in and keep profits from collapsing. In "bad times" when the 
real exchange rate weakens this extra support could be taken away. The policy is not unrelated to the "price bands" that protects sensitive agricultural products in many countries.

This logic has a strong partial equilibrium flavor. Does it survive the general equilibrium logic? After all, the changes in relative prices in this model are equilibrium movements. In the logic of our model, these are the required prices needed to clear both the market for non-tradables and the labor market. Interfering with these relative price changes would likely cause even larger changes in underlying prices in order to achieve the requisite reallocation.

However, the policy may survive the general equilibrium counter-forces provided it can assure investors that ex post returns will be sufficiently stable. The existence of more capital in the tradable sector does not prevent the sector from shedding labor in "good times" while it is there to absorb it in "bad times". So, labor can still move between sectors, and since it will be working with more capital, will therefore be more productive. Moreover, if the tradable sector is substantial, its ability to absorb and shed labor will lower the volatility of the economy, reduce interest rates and support even more capital in the economy.

Furthermore, while in our model movements in relative prices are caused by fundamental forces, in real life they may reflect other shocks and distortions 
which are less stabilizing. Protecting the tradable sector form their consequences may also be welfare enhancing.

Thus, we find some rationale for state-contingent protection. Obviously, one important drawback is that political economy forces may prevent the government from lowering tariffs and export subsidies when the real exchange rate is weak or may lead to excessive protectionism. However, it is not obvious that trade policy is the most efficient instrument. Further analysis is surely called for.

\section{Financial Support for Tradables}

Trade policy operates by changing the relative prices for goods faced by the whole economy. An alternative approach would be to offer some form of financial assistance to the tradable sector, without getting involved directly in the price setting process in the goods market. A financial intervention that increases the stock of capital in the tradable sector can help push the economy out of specialization. One instrument to consider is some form of financial guarantee. This guarantee can be made contingent not on the idiosyncratic risks of a project but instead on the real exchange rate, so as to limit moral hazard. Through this mechanism, the probability of having to incur in a costly bankruptcies would be reduced calling for lower interest rates. If this helps increase the size of the tradable sector, overall volatility might be reduced. However, at least in the 
transition to a more diversified economy, these guarantees might be exercised with significant frequency, so the potential fiscal liabilities must be considered. However, it is important to remember that, at least in the typical case, the real exchange rate appreciates in good times, when oil revenues are high and the government spends too much. Having this financial guarantee in place might constitute a mechanism that "punishes the government" for overspending booms and thus might have the right incentive properties from a political economy perspective: it gives the tradable sector a contingent claim on future oil booms that might otherwise lead to their demise.

Having said this, it is important to remember that in practice, money is fungible and that the tradable sector is not precisely defined in real life. Moreover, any initiative involving public monies will be subject to political economy distortions. 


\section{BIBLIOGRAPHY}

Aizenman, Joshua and Nancy Marion (1999) "Volatility and Investment: Interpreting Evidence from Developing Countries," Economica, 66, pp. 157 - 79.

Auty, R.M.(1990) "Resource-Based Industrialization: Sowing the Oil in Eight Developing Countries". New York; Oxford University Press.

Caballero, Ricardo and R. Pindyck (1996) "Uncertainty, Investment, and Industry Evolution” International Economic Review 37(3), August 1996, 641-662.

Caballero, Ricardo J. (1991) "Irreversibility and non-robustness of the investment - uncertainty relationship”, American Economic Review, March.

Caballero, Ricardo (1991) "On the Sign of the Investment Uncertainty

Relationship,” American Economic Review 81(1), March 1991, 279-288.

Caballero, Ricardo (2000) "Macroeconomic Volatility in Latin America: A View and Three Case Studies" Economia, September.

Corden, W.M. (1982), "Exchange Rate Policy and the Resources Boom," Economic Record 58(160): 18-31, March.

Corden, W.M. and J.P. Neary (1984) "Booming sector and de-industrialisation in a small open economy," Economic Journal, 92, 825-48; reprinted in W.M.

Corden: Protection, Growth and Trade: Essays in International Economics, Oxford: Basil Blackwell, 1985; and in W.M. Corden: International Trade Theory and Policy: Selected Essays of W. Max Corden, Aldershot: Edward Elgar, 1992.

Duryea, Suzanne (1998) “Children's Advancement Through School in Brazil: The Role of Transitory Shocks to Household Income", Inter-American Development Bank WP-376, Jul 1998.

Flug, Karnit, Antonio Spilimbergo and Eric Wachtenheim (1999). "Investment in Education: Do Economic Volatility and Credit Constraints Matter?," Journal of Development Economics, vol. 55, no. 2. 
Gavin, Michael and Ricardo Hausmann, (1996) "Securing Stability and Growth in a Shock Prone Region: The Policy Challenge for Latin America" IDB, WP-315.

Gavin, Michael and Ricardo Hausmann, (1998) "Nature, Development, and Distribution in Latin America. Evidence on the Role of Geography, Climate, and Natural Resources," WP-378.

Hartman, R. (1972) "The effects of price and cost uncertainty on investment," Journal of Economic Theory. 1972; 5258-266.

Hausmann, Ricardo (August 2001) Working Paper, "Venezuela's growth implosion: A neo-classical story?"

Hausmann, Ricardo, Andrew Powell, , and Roberto Rigobon, (1993) “An Optimal Spending Rule Facing Oil Income Uncertainty (Venezuela)', in Engel, Eduardo and Meller, Patricio, eds. External shocks and stabilization mechanisms. Washington, D.C.: Inter-American Development Bank; distributed by Johns Hopkins University Press, 1993, pp. 113-71.

Higgins, M. and J. G. Williamson, (1999) "Explaining Inequality the World Round: Cohort Size, Kuznets Curves, and Openness," NBER Working Paper 7224, National Bureau of Economic Research, Cambridge, Mass.

IDB (1995) Economic and Social Progress in Latin America 1995 Report.

Johnsen, Cristopher, Kenneth A Shepsle, and Barry R. Weingast (1981) "The Political Economy of Benefits and Costs: A Neo-classical Approach to Distributive Politics" Journal of Political Economy, 89 (5).

Karl, Terry Lynn (1997) "The paradox of plenty: oil booms and petro-states." Berkely: University of California Press.

Lane, Phillip R and Aaron Tornell (1999) "Voracity and Growth in Discrete Time”, Economic Letters, Vol. 62, no. 1(January 1999): 139-145.

Lane, Philip R. and Aaron Tornell(1999) "The Voracity Effect," American Economic Review, 89, 22-46.

Maddison, Angus, Monitoring the world economy: 1820-1992, (1995) Development Centre Studies. Paris and Washington, D.C.: Organisation for Economic Cooperation and Development. 
Manzano, Osmel and Roberto Rigobon, (2001) "Resource Curse or Debt Overhang?," NBER Working Papers 8390, National Bureau of Economic Research, Inc.

Matsuyama, Kiminori (1992) "Agricultural Productivity, Comparative Advantage and Economic Growth", Journal of Economic Theory, December.

Ramey, Garey and Valerie A. Ramey (1995) "Cross-Country Evidence on the Link Between Volatility and Growth" American Economic Review 85, 1138 1151.

Sachs, J. D. and A. M Warner. (1995) Economic reform and the process of global integration. Brookings Papers on Economic Activity, 1-118.

Sachs, Jeffrey and Andrew Warner (1997) "Natural resource abundance and economic growth", mimeo, Center for international Development, Harvard University.

Von Hagen, Jürgen and Ian J. Harden (1994) "National Budget Processes and Fiscal Peformance", The European Economy, 311-418. 
Figure 1. GDP per capita at purchasing power parity for different countries

\section{Saudi Arabia}

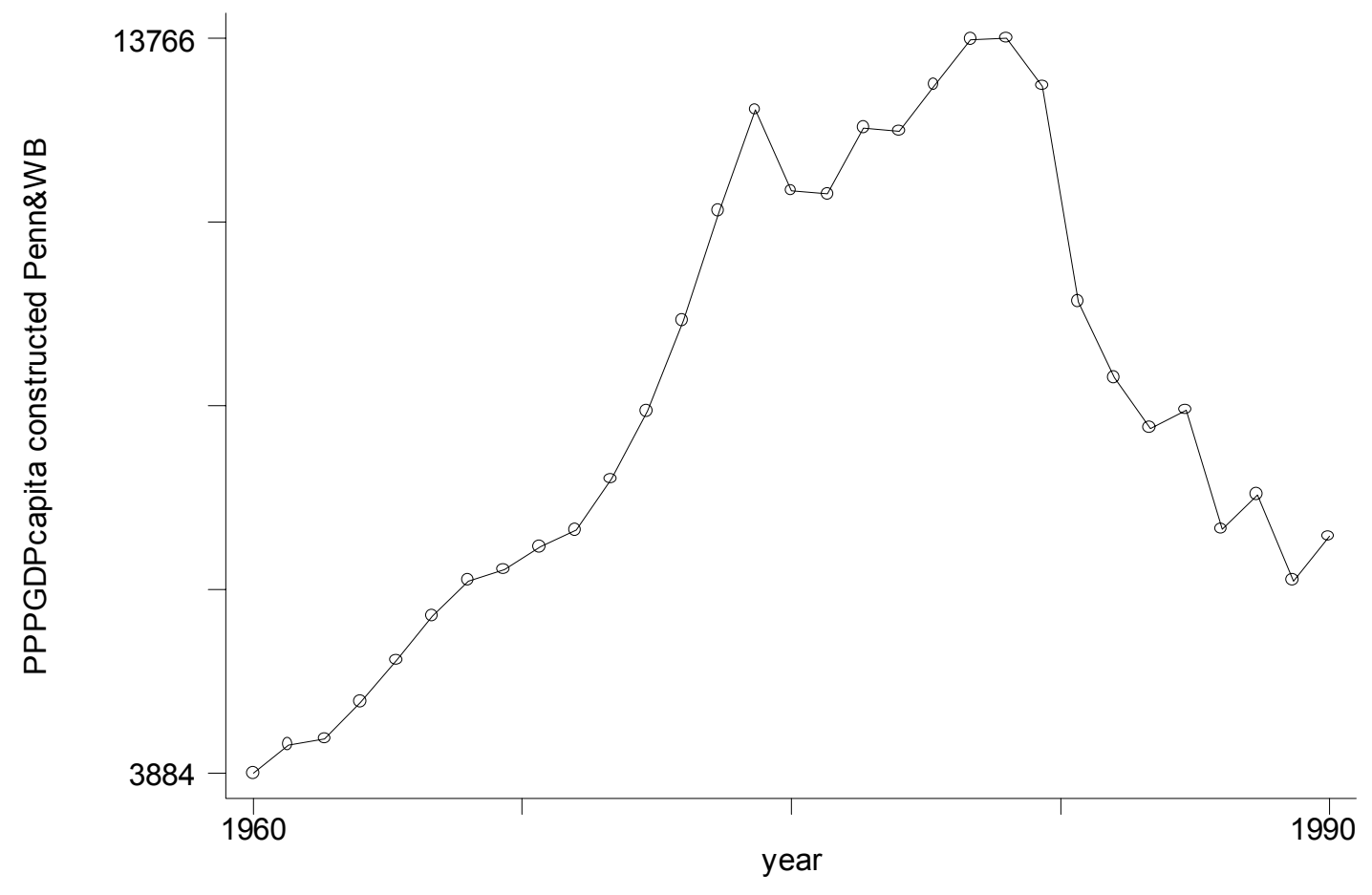

Zaire

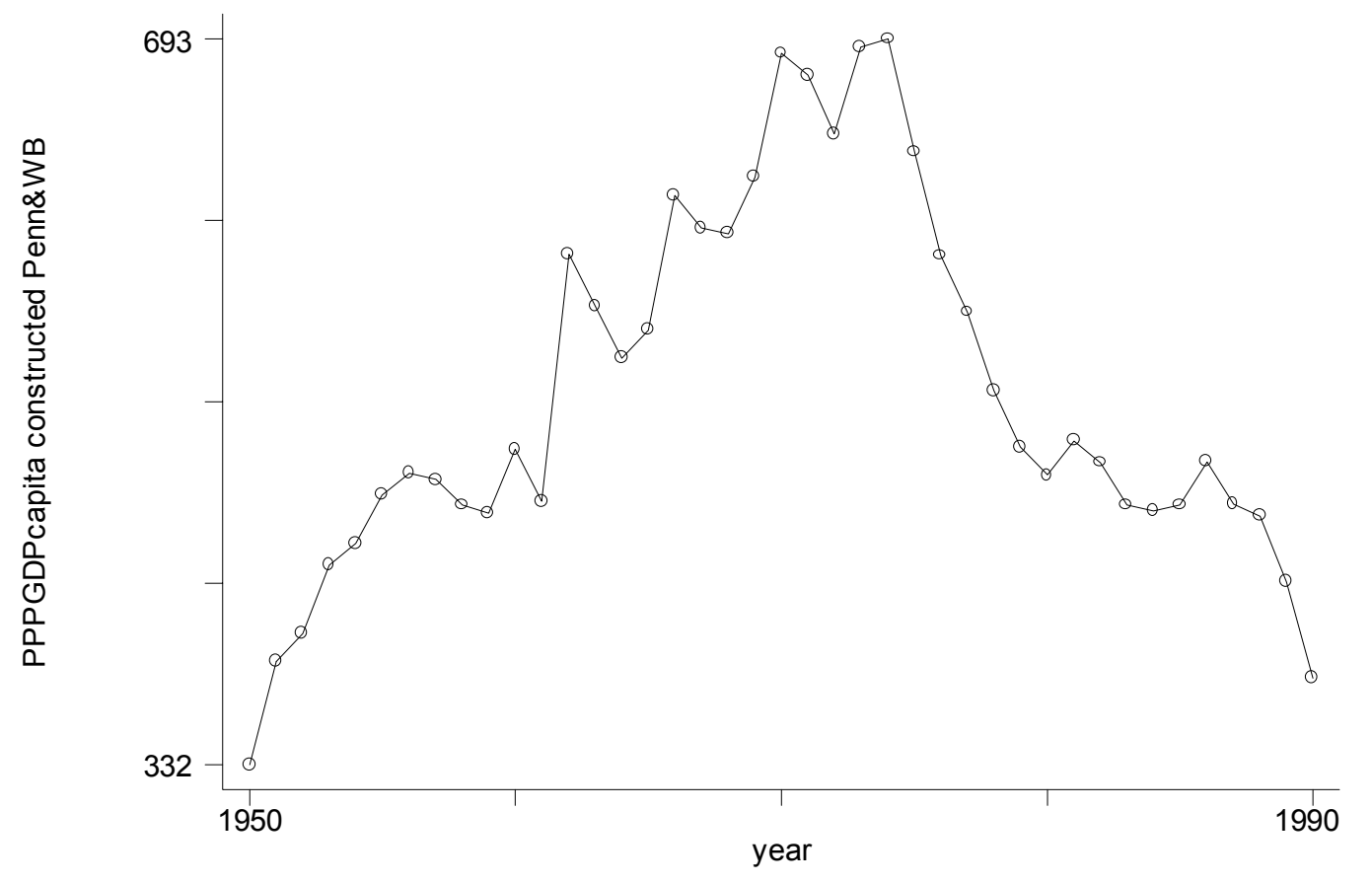




\section{Mexico}

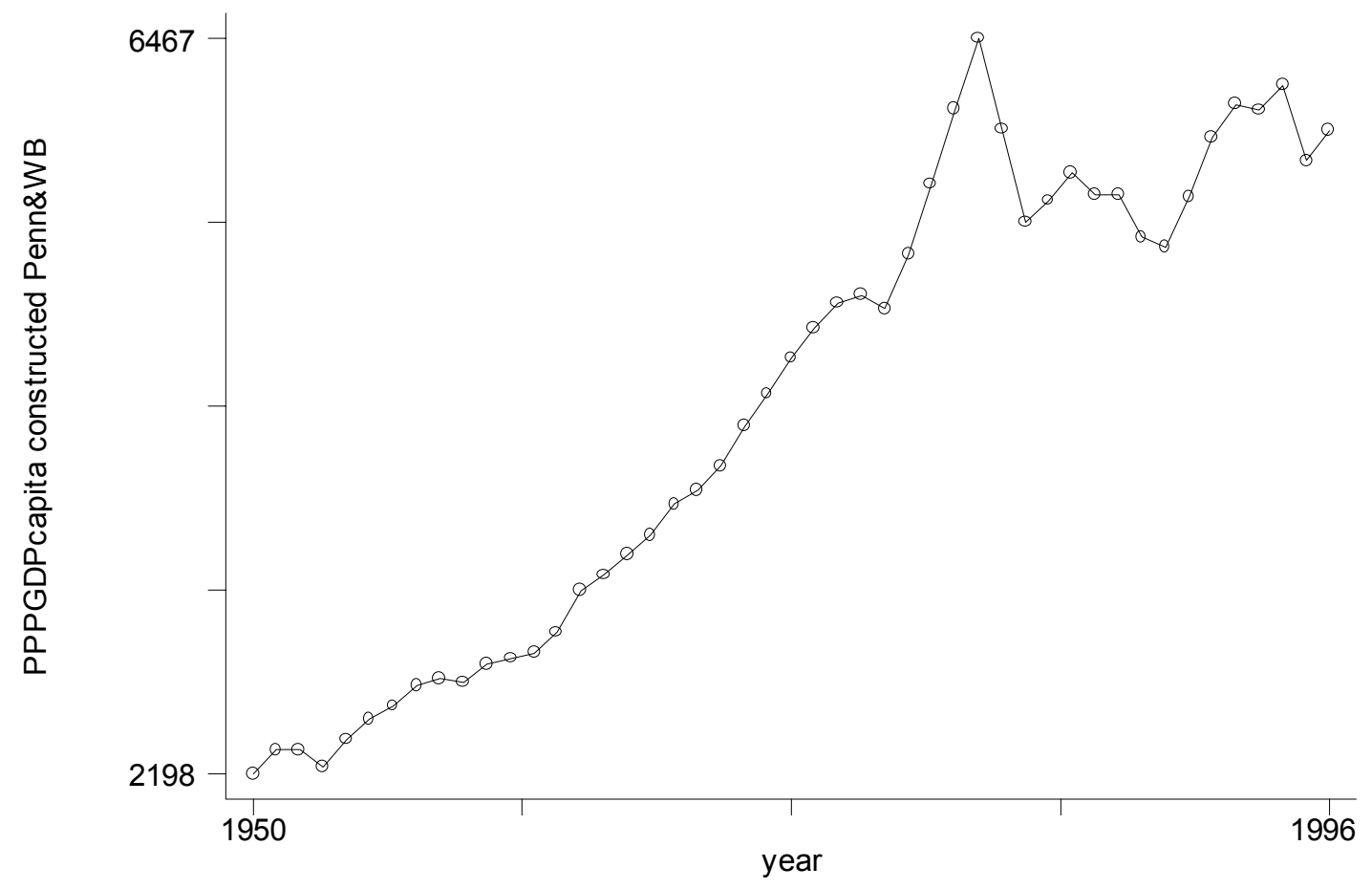

Indonesia

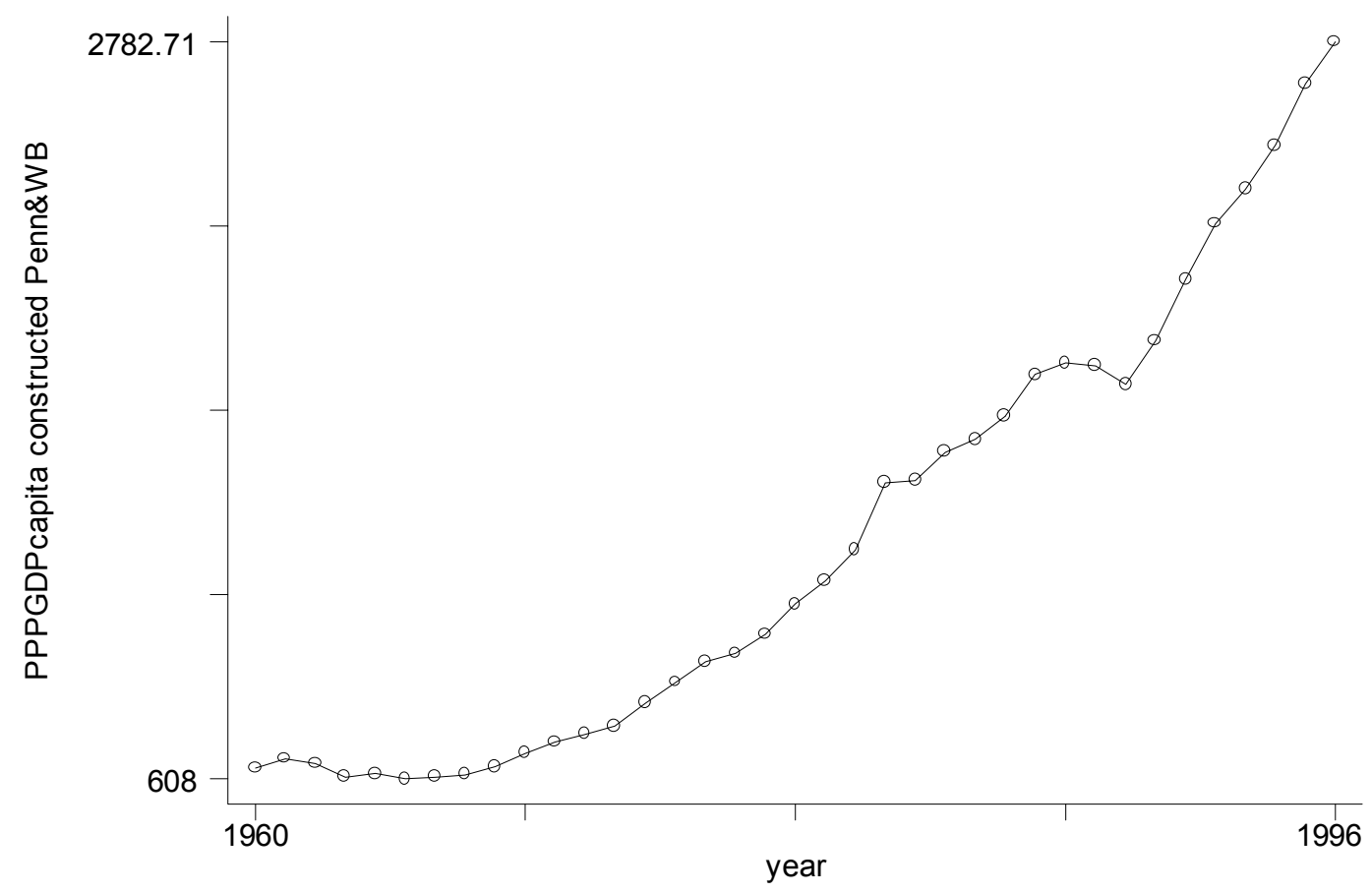




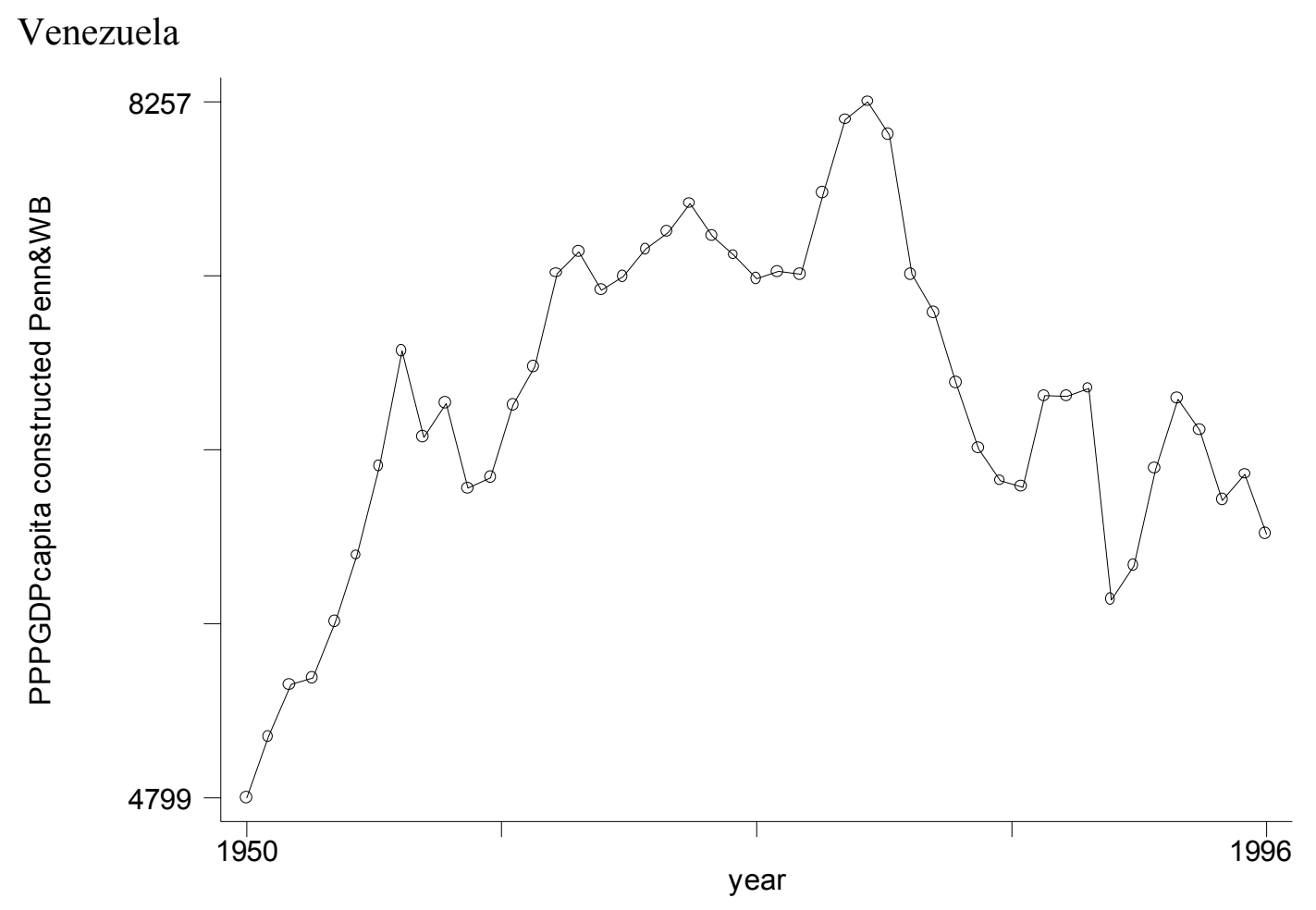

Nigeria

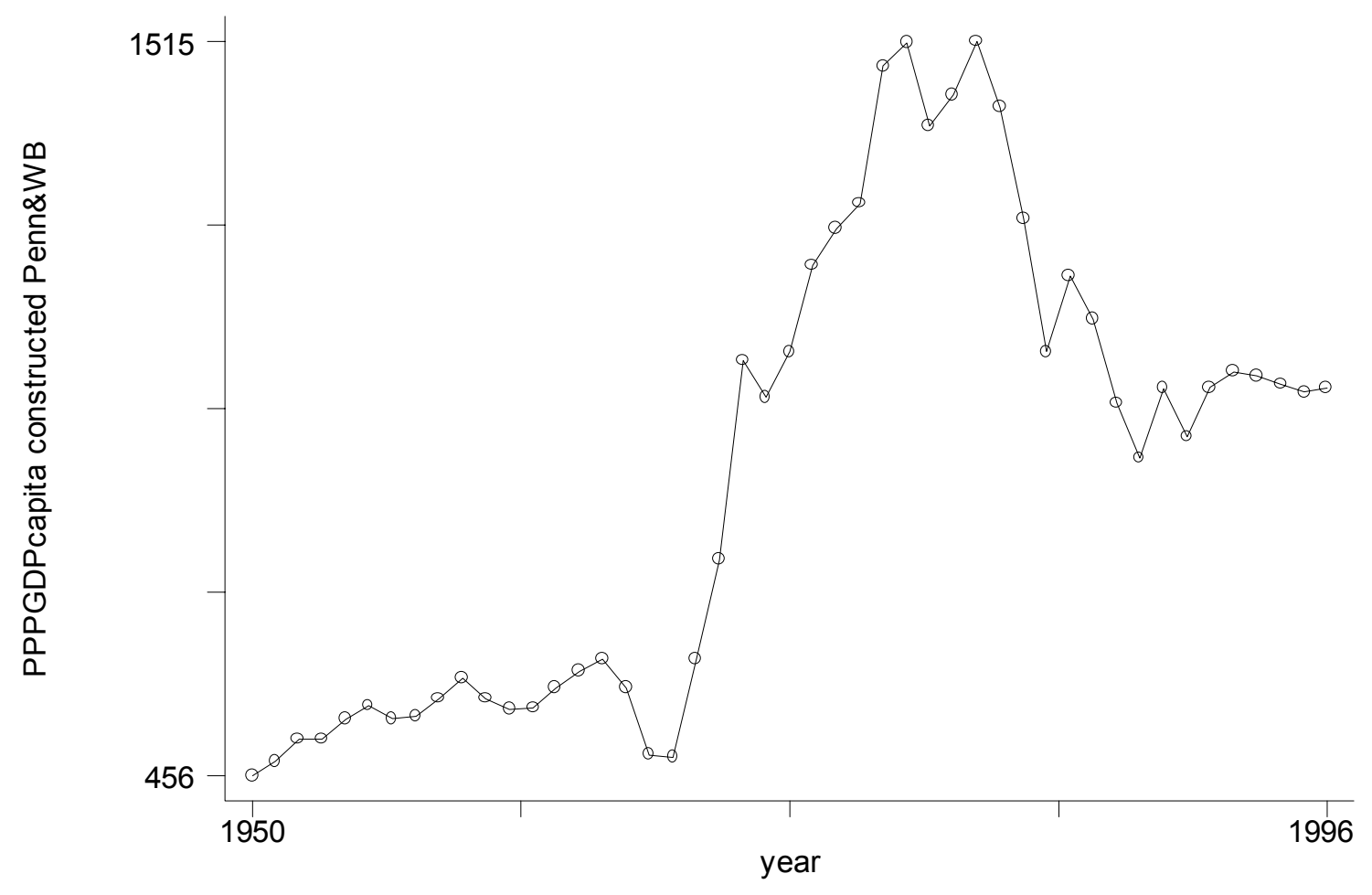


Figure 2

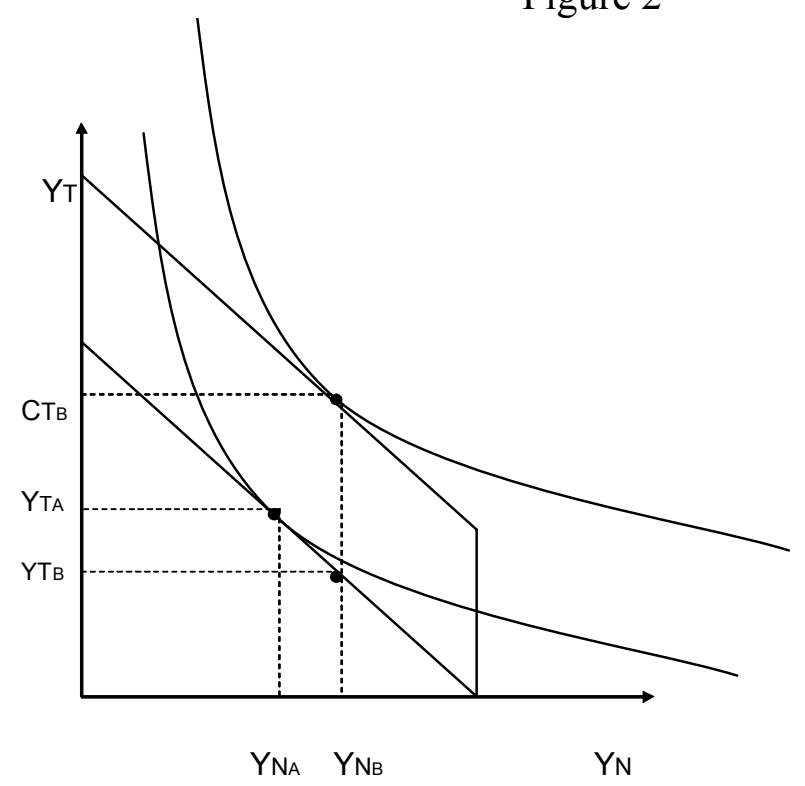

THE BENCHMARK MODEL: THE DIVERSIFIED ECONOMY 
Figure 3

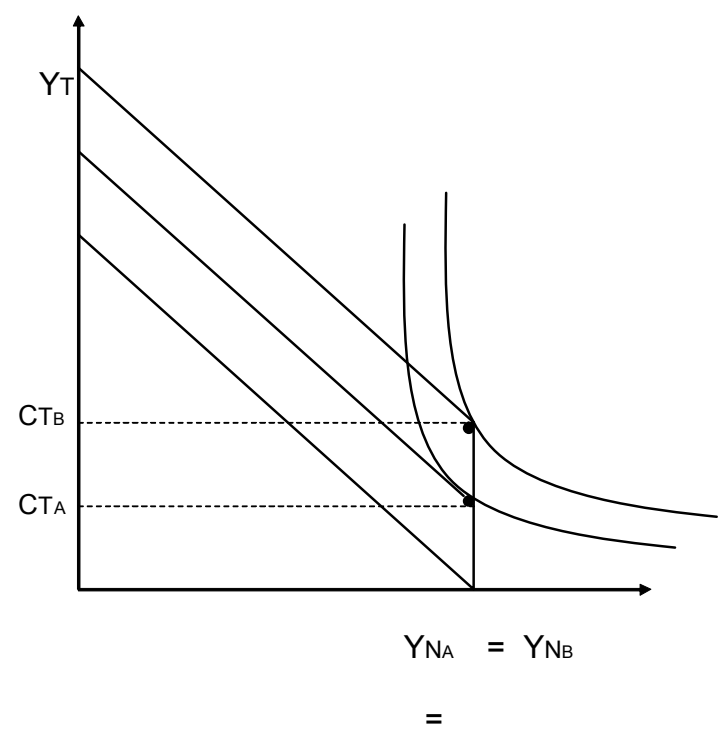

THE BENCHMARK MODEL: THE SPECIALIZEDIED ECONOMY

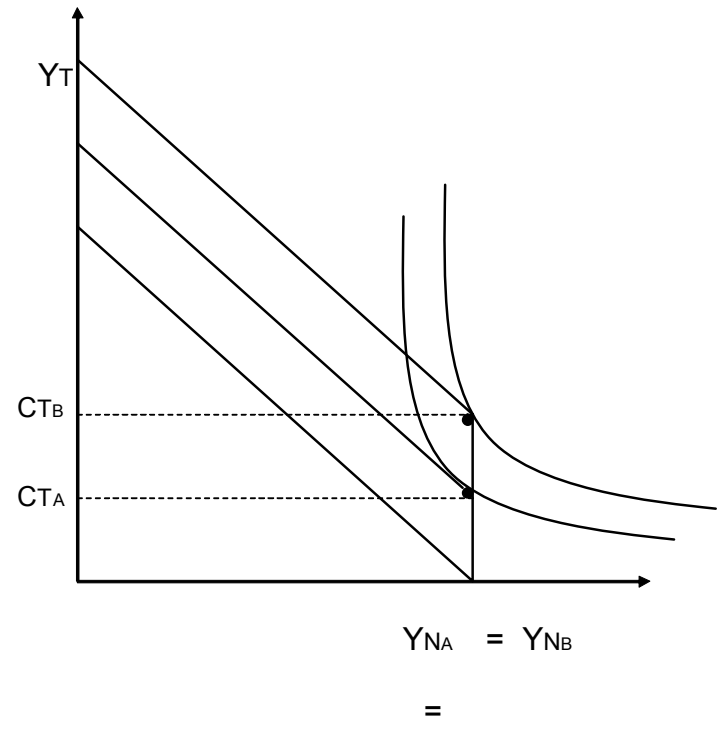

THE BENCHMARK MODEL: THE SPECIALIZEDIED ECONOMY 
Figure 4.

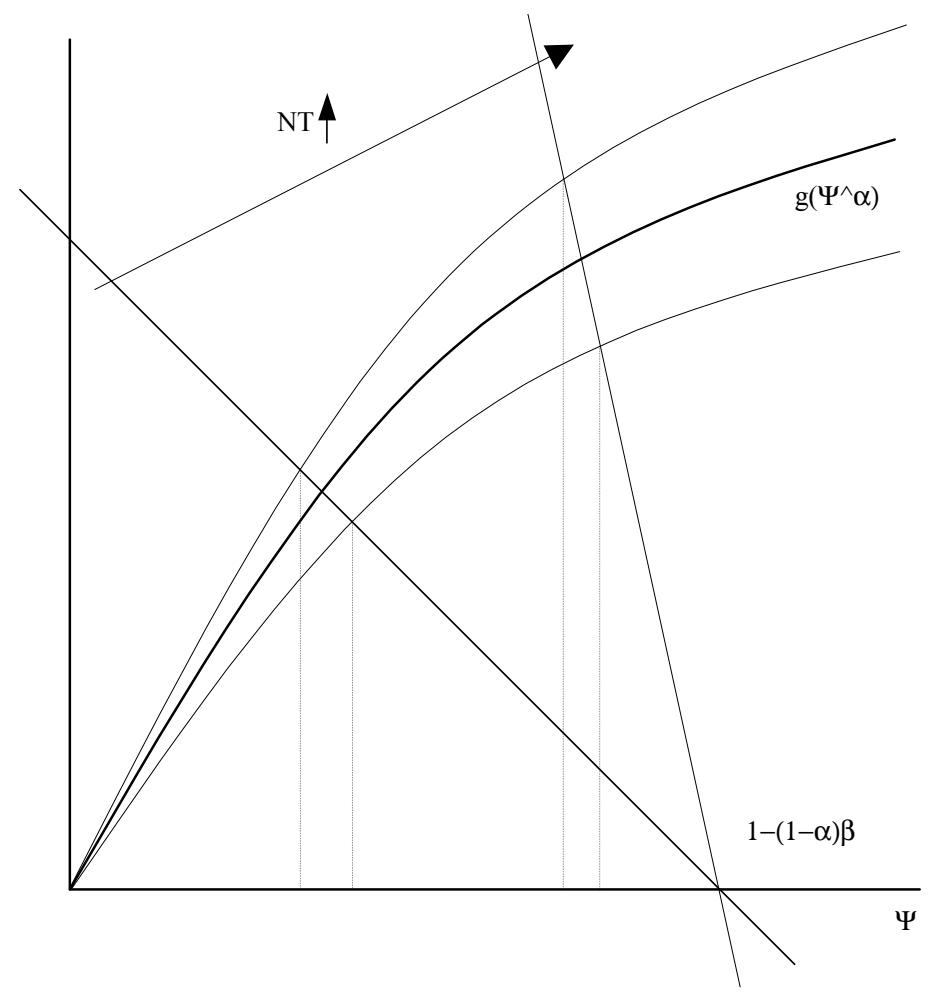


Figure 5. Simulation: the risk neutral case

5.a Number of non-tradable firms

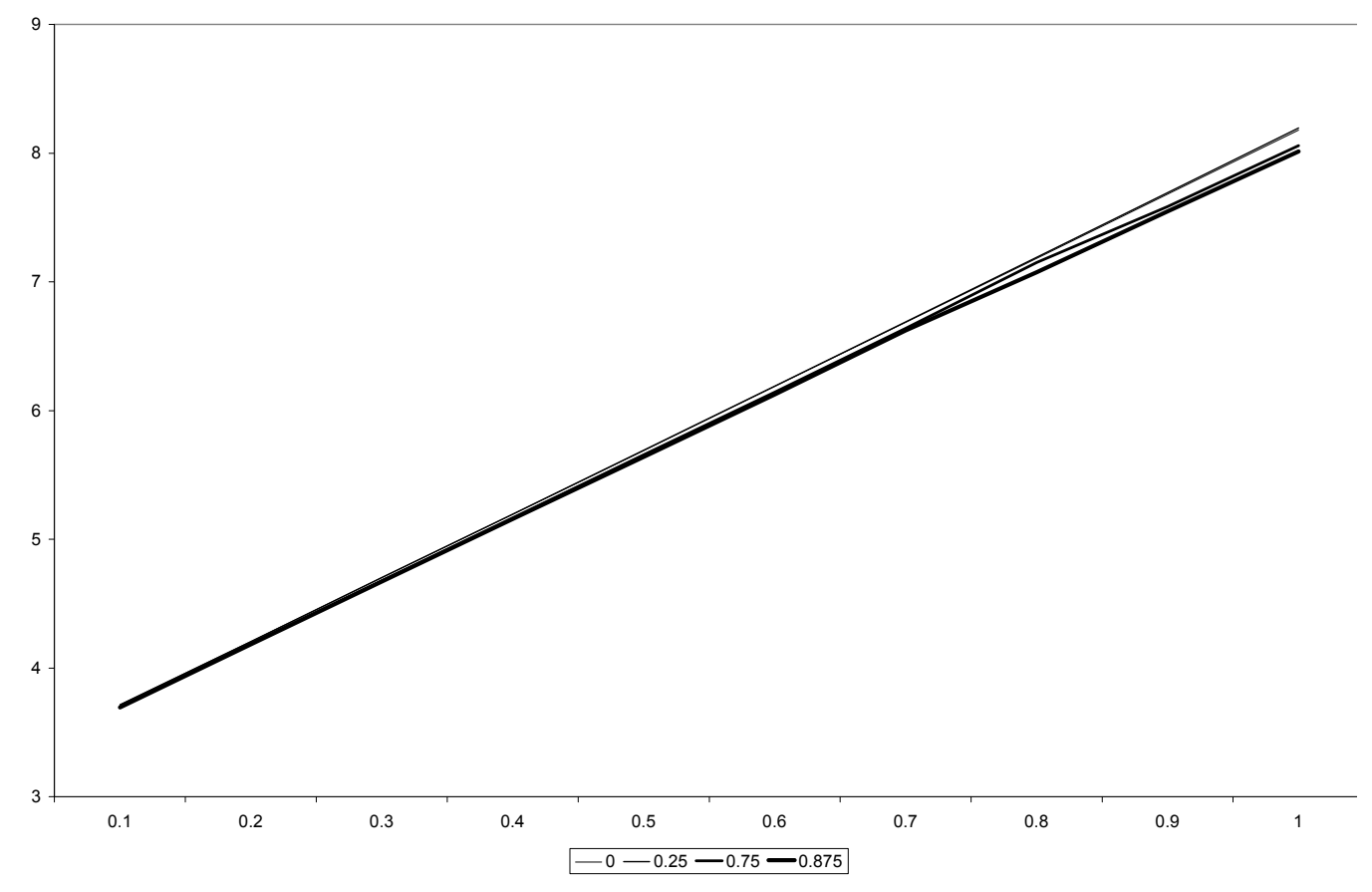

5.b Number of tradable firms

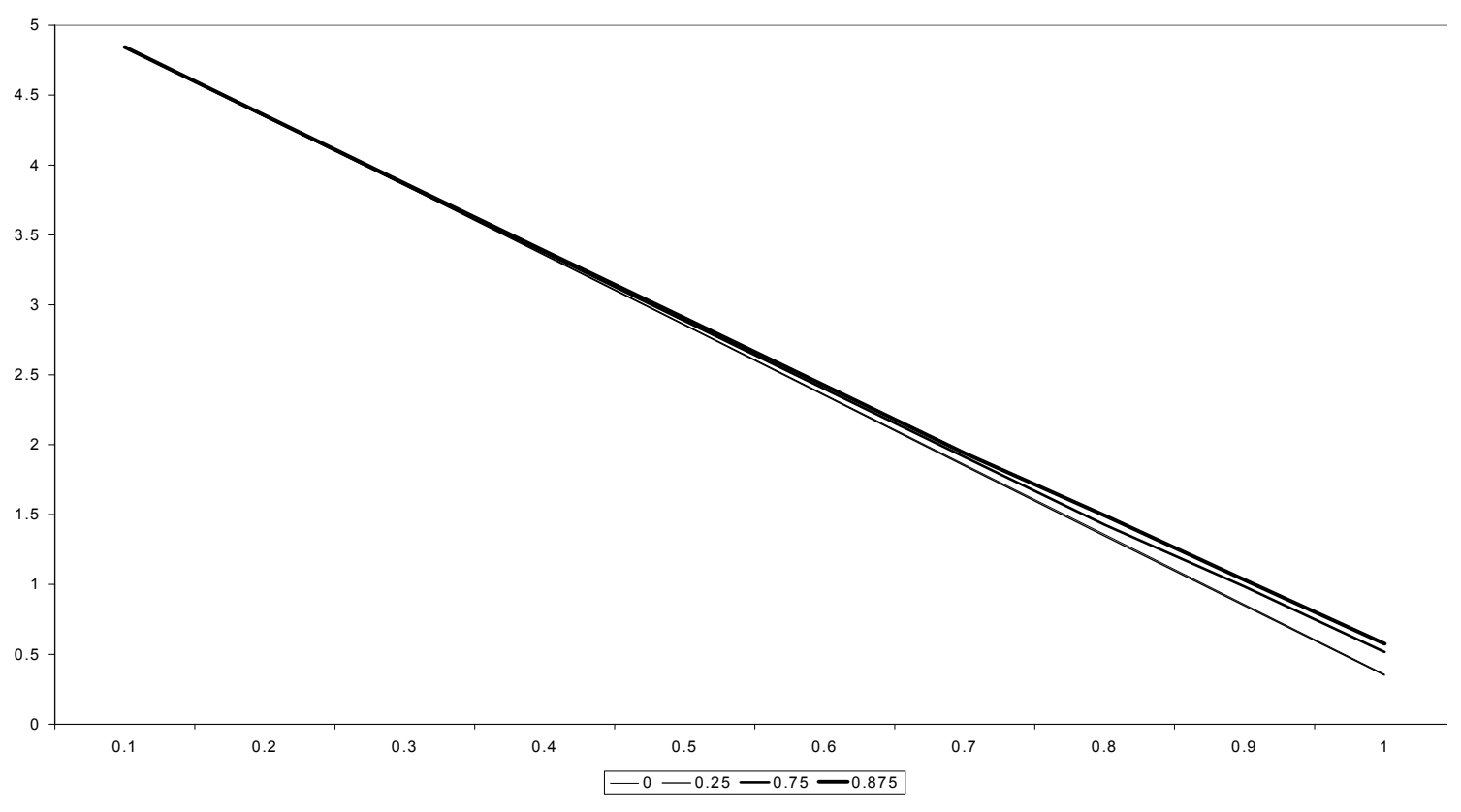




\section{5.c Household utility}

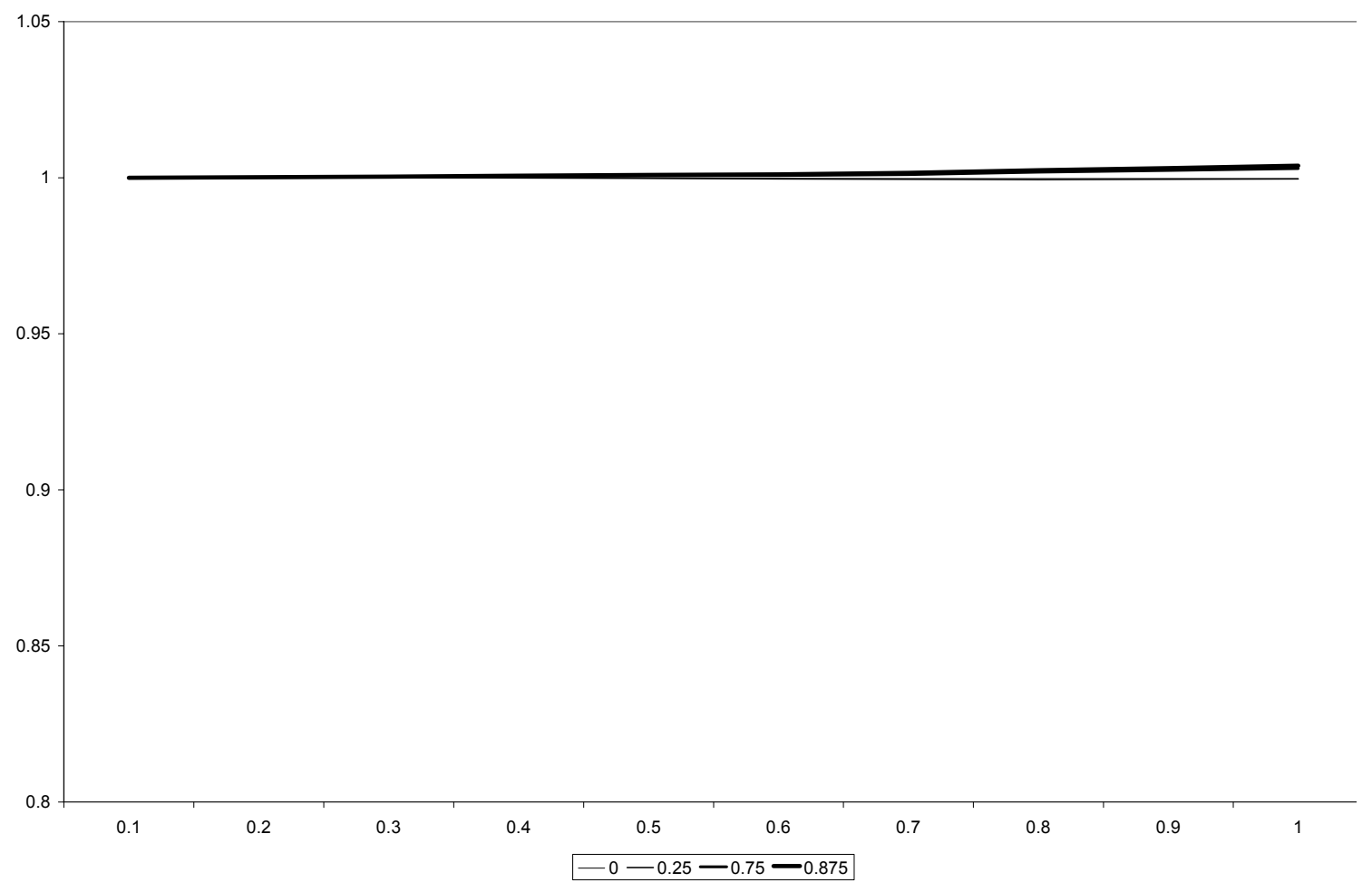

5.d Real exchange rate volatility

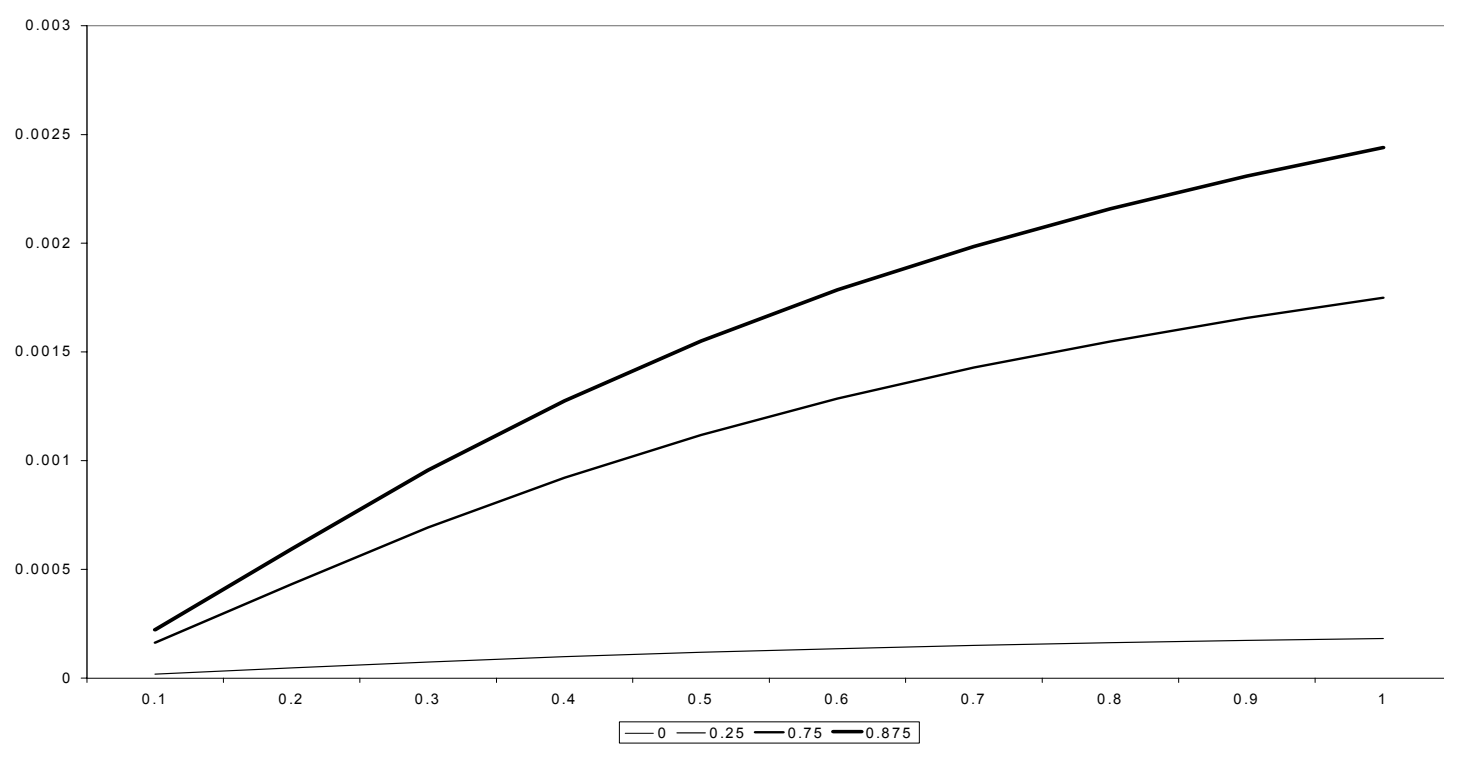


Figure 6. Silmulation: the risk-averse case

6.a The number of non-tradable firms

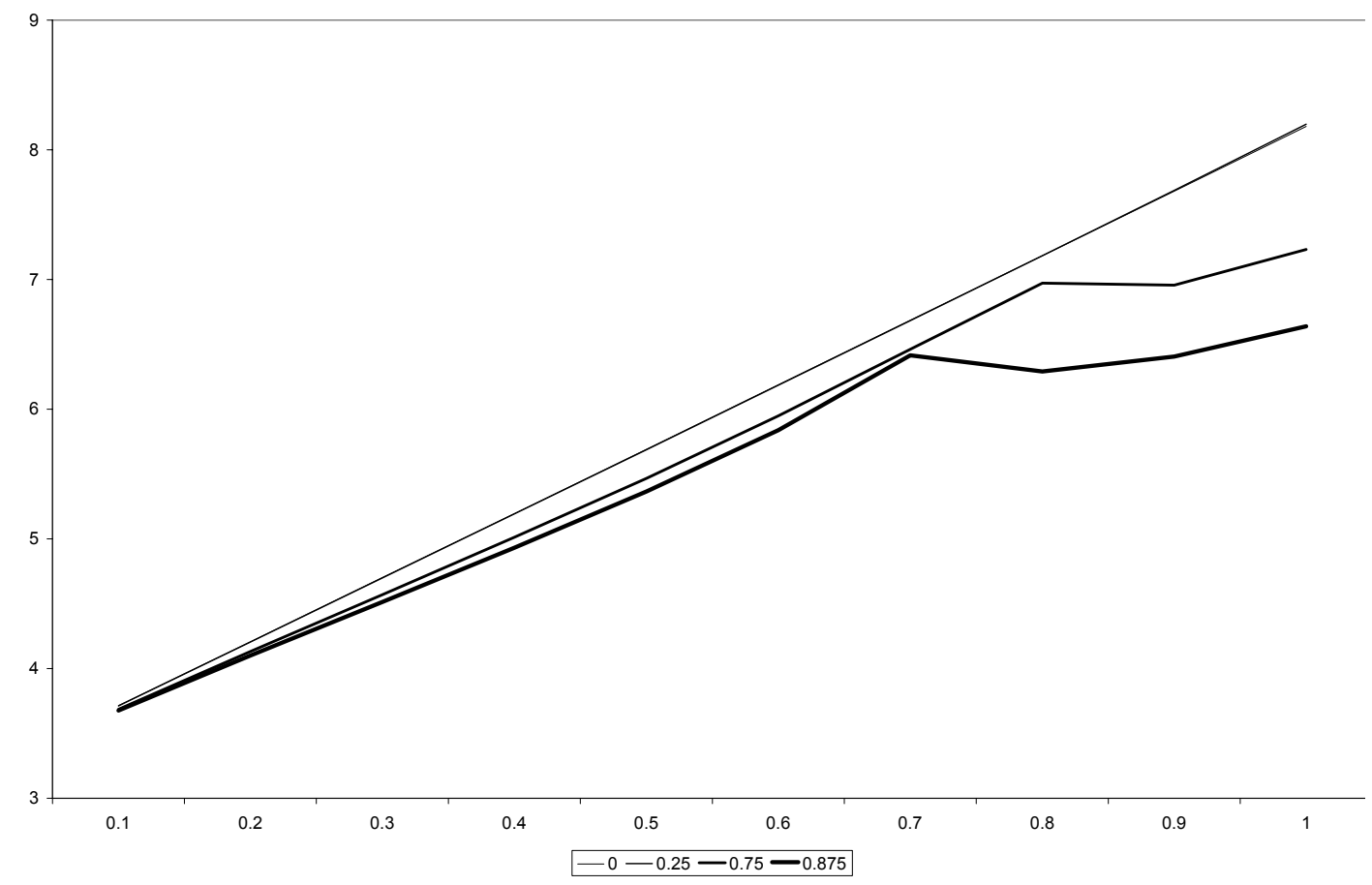




\section{6.b The number of tradable firms}

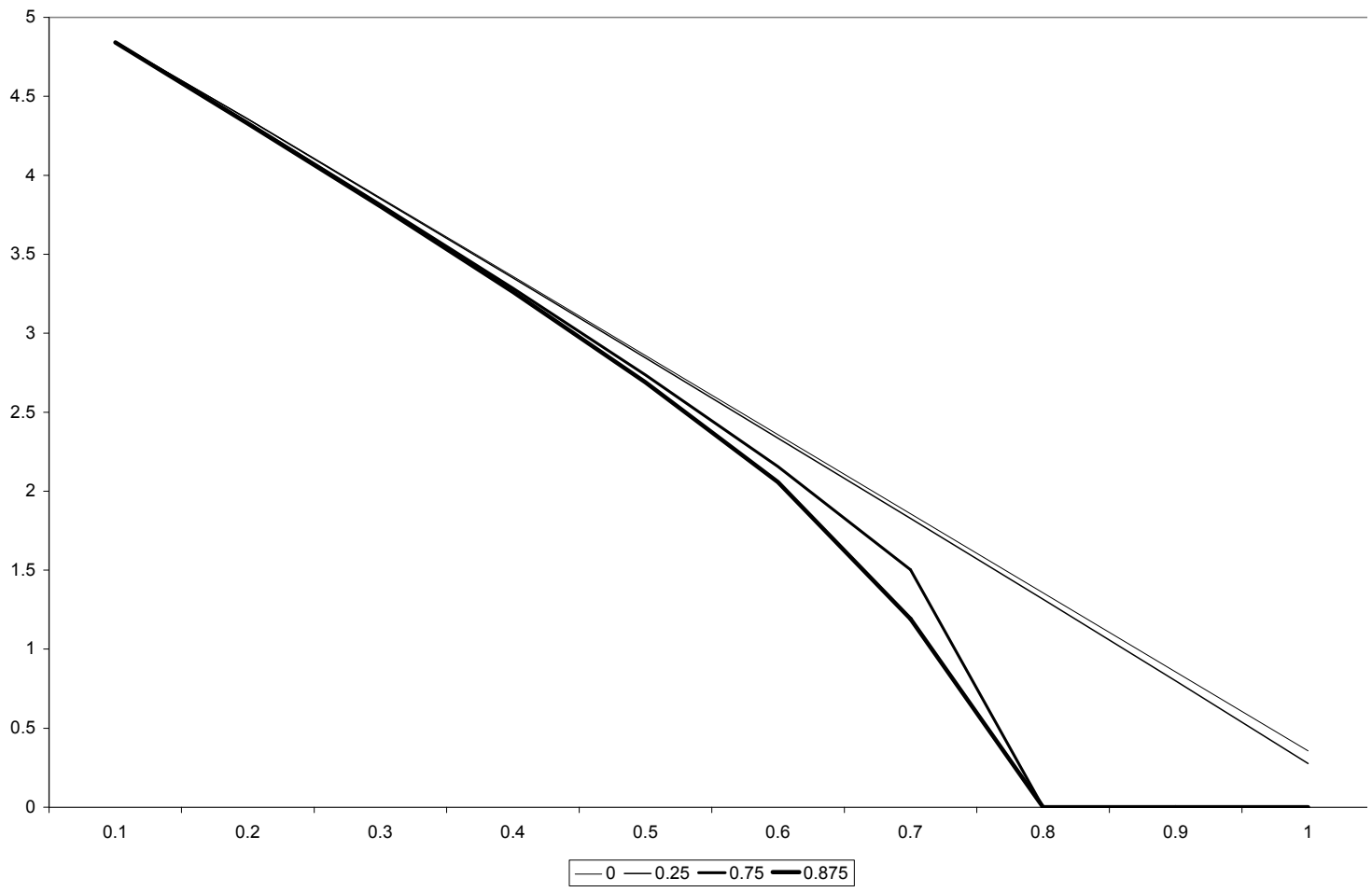


6.c Household utility

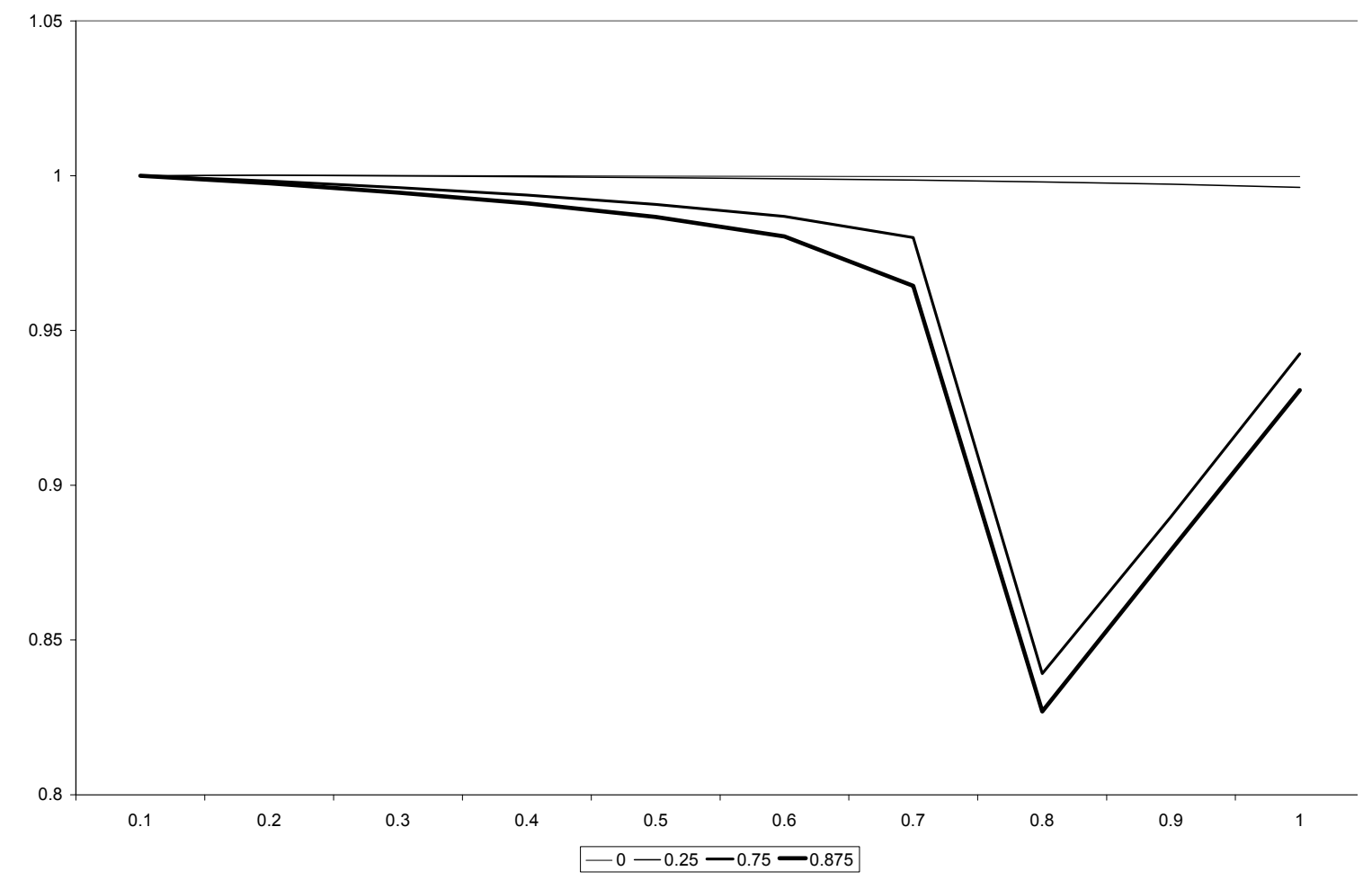


6.d Real exchange rate volatility

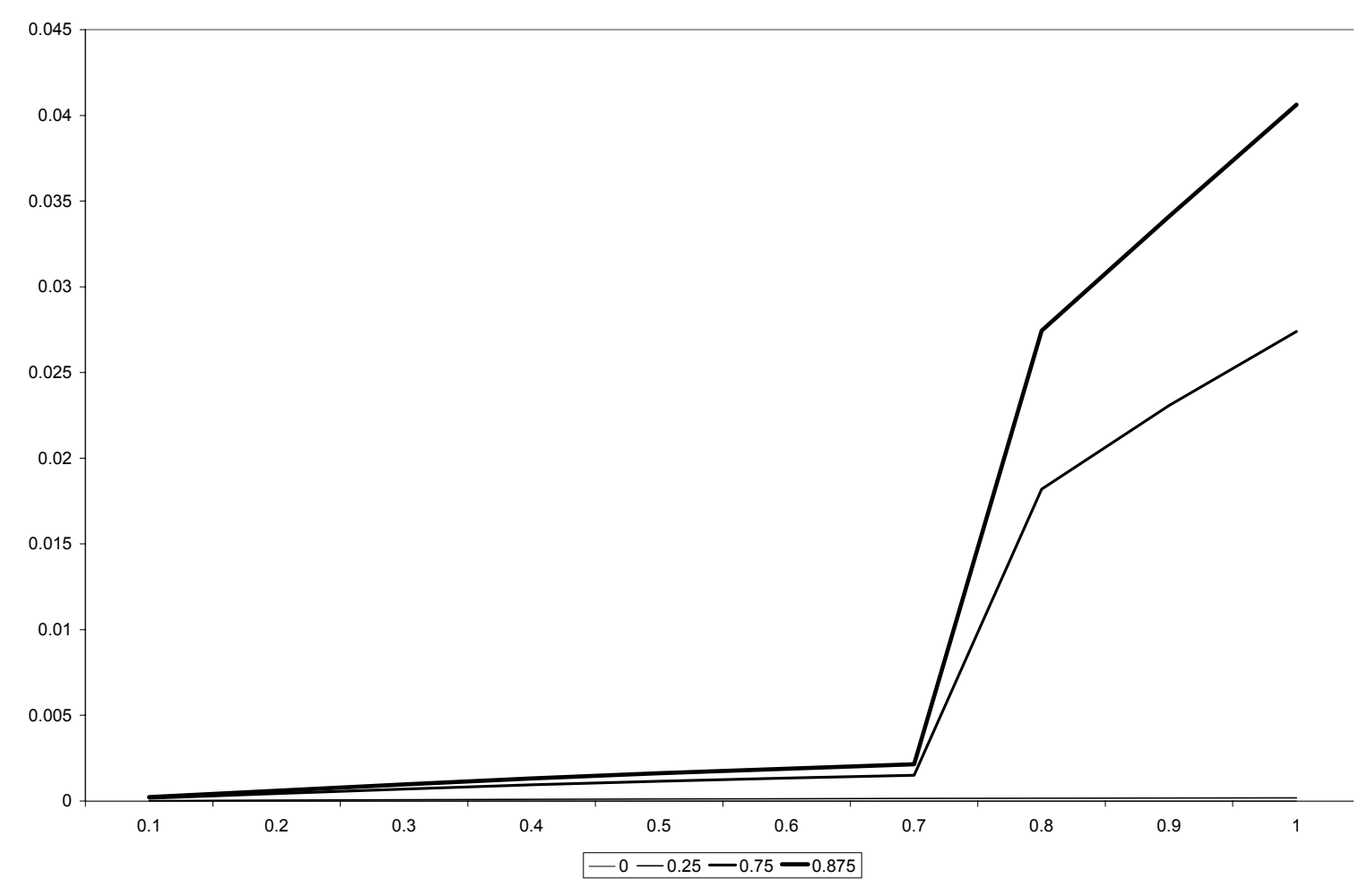

